\title{
The Warnie Volcanic Province: A Jurassic Volcanic Province in Central Australia
}

\author{
Jonathon P.A. Hardman', Simon P. Holford², Nick Schofield', Mark Bunch² Daniel Gibbins ${ }^{3}$
}

'Department of Geology and Petroleum Geology, University of Aberdeen, Aberdeen, AB24 3FX, UK

${ }^{2}$ Australian School of Petroleum, University of Adelaide, Adelaide, SA 5005, Australia

${ }^{3}$ Vintage Energy, 58 King William Road, Goodwood SA 5034, Australia

e-mail: simon.holford@adelaide.edu.au

\begin{abstract}
The Cooper and Eromanga Basins of South Australia and Queensland are the largest onshore hydrocarbon producing region in Australia. Igneous rocks have been documented infrequently within end of well reports over the past 34 years, with a late Triassic to Jurassic age determined from well data. However, the areal extent and nature of these basaltic rocks were largely unclear. Here, we integrate seismic, well, gravity and magnetic data to clarify the extent and character of igneous rocks preserved within Eromanga Basin stratigraphy overlying the Nappamerri Trough of the Cooper Basin. We recognise mafic monogenetic volcanoes that extend into tabular basalt lava flows, igneous intrusions and, more locally, hydrothermally altered compound lava flows. The volcanic province covers $\sim 7500 \mathrm{~km}^{2}$ and is proposed to have been active between $\sim 180-160 \mathrm{Ma}$. We deem this Jurassic volcanic province the Warnie Volcanic Province after the Warnie East I exploration well, drilled in 1985. The distribution of extrusive and intrusive igneous rocks is primarily controlled by basement structure, with extrusive and intrusive igneous rocks elongate in a NW-SE direction. Finally, we detail how the WVP fits into the record of Jurassic volcanism in eastern Australia. The WVP is interpreted as a product of extension and intraplate convective upwelling above the subducting Pacific Slab. The discovery of the WVP raises the possibility of other, yet unidentified, volcanic provinces worldwide.
\end{abstract}

\section{Keywords}

Intraplate; volcanism; monogenetic; Australia; Jurassic

\section{Introduction}

The Cooper and the overlying Eromanga Basin extend for $130,000 \mathrm{~km}^{2}$ and $1,000,000 \mathrm{~km}^{2}$ respectively across central, north and eastern Australia. Together, they represent the largest conventional onshore hydrocarbon-producing region in Australia (Hall, 20l6). The first gas discovery was made in 1963 and since then, over I,400 producing wells have been drilled, with 190 gas and II 5 oil fields discovered throughout both basins (Fig. I) (Mackie, 20I5). The majority of discoveries within the Cooper Basin are situated within structural traps on regional highs, however, a number of companies began to pursue unconventional hydrocarbon 
plays within the basin during the late 2000 s, resulting in an increase in activity within the Nappamerri Trough (Hillis et al., 200 I; Pitkin et al., 20I2; Khair et al., 20I3; Scott et al., 20I3; Hall et al., 2016). The Nappamerri Trough is the largest and deepest depocentre within the Cooper Basin covering $\sim 10,000 \mathrm{~km}^{2}$ and reaching present day depths of $\sim 4.5 \mathrm{~km}$ (Fig. IA). The acquisition of new well and seismic data due to the exploration activities has resulted in the increased recognition of igneous rocks in the Cooper and Eromanga Basins.

Igneous rocks of suspected late Triassic-Jurassic age have been sporadically encountered by drilling during the past 34 years (Short, 1984; Boothby, 1986; Bucknill, 1990; Allen, 1998), though there has been no systematic study of the character, origin and significance of these igneous rocks. Here, we combine extensive seismic, well and airborne geophysical data to document the extent and character of Mesozoic volcanics recognised within Eromanga Basin stratigraphy overlying the Nappamerri Trough of Cooper Basin age. The Warnie Volcanic Province (WVP) is the suggested name for this $>7,500 \mathrm{~km}^{2}$ suite of volcanics identified within the Jurassic succession of the Eromanga Basin (Fig. IB). The province is named after the Warnie East I exploration well, which was drilled in 1985 and encountered $65 \mathrm{~m}$ of basalt. We provide an in-depth study of the regional implications of the WVP for the Cooper and Eromanga Basins. We find that SE-NW intracratonic sag faulting (Kulikowski et al., 20I5) controlled the morphology of igneous rocks whilst the basin structure likely controlled the location of igneous rocks.

Finally, we discuss the origin of the WVP. Evidence for Triassic to mid-Cretaceous volcanic activity is pervasive throughout the sedimentary basins of central Australia, manifested by an influx of volcanic arc-derived sediment into the Eromanga Basin (Boult et al., 1998), silicic tuffs in the Surat Basin (Wainman et al., 2015) and widespread volcanogenic zircons throughout the Great Artesian Basin (Bryan et al., 1997). However, the origin of intraplate volcanism is contentious and can be difficult to isolate from tectonic processes occurring close to the region of volcanism (Conrad et al., 20II; Zhou et al., 2018). The WVP was located $>500 \mathrm{~km}$ away from a significant plate boundary during the Jurassic. It is therefore important to consider the source of this volcanism and the tectonic implications for central Australia. We theorise that the WVP's geodynamic origin is ultimately linked to subduction at the eastern margin of Gondwana, through asthenospheric shear $\sim 1500 \mathrm{~km}$ from the oceanic trench, however, we also discuss other mechanisms that can produce intraplate volcanism. Our discovery of a previously undescribed volcanic province in an area that has undergone $>50$ years of extensive subsurface data collection due to continued hydrocarbon exploration, 
raises the prospect of other undiscovered intraplate volcanic provinces both in Australia and in other continental areas worldwide.

\section{Geological Overview of the Cooper and Eromanga Basins}

The geology of southwest Queensland and northeast South Australia, central Australia, is defined by a series of intracratonic basins stacked on top of each other; the Warburton, Cooper, Eromanga and Lake Eyre Basins (Fig. 2 \& Fig. 3).

The Warburton Basin is a lower Palaeozoic sedimentary basin that hosted Silurian to Carboniferous granite emplacement (Murray 1986; Boucher 1997; Alexander et al., 1998). The Cooper Basin unconformably overlies the Warburton Basin. The Cooper Basin is a northeast to southwest trending intracratonic structural depression that accommodated the deposition of sedimentary rocks from the late Carboniferous to the Middle Triassic (Laws \& Gravestock, 1998). Several tectonic origins for the Cooper Basin have been suggested, including a mildly compressional structural depression (Apak, 1994 \& Sun, 1997), a depression created through wrenching (Kuang, 1985) and extension during post-compression flexural relaxation (Kulikowski et al., 2015). Deposition throughout the early Permian was dominated by highly sinuous fluvial systems situated on a major floodplain with peat rich swamps and lakes (Abul Khair et al., 2015). Later Triassic deposition took place in a period of tectonic quiescence (Gravestock et al., 1998).

Deposition in the Cooper Basin was terminated by regional uplift, compressional folding and erosion in the middle Triassic. The Cooper Basin is unconformably overlain by the Eromanga Basin, which forms part of the Great Artesian Superbasin (GAB), a group of interconnected basins that cover much of Queensland, South Australia and New South Wales. The Eromanga Basin is an intracratonic sag basin whose subsidence has been attributed to dynamic topography induced by subduction of the pacific plate below Australia (Gallagher \& Lambeck, 1989; Russell \& Gurnis, 1994; Matthews et al., 201I). Deposition within the Eromanga Basin was controlled by subsidence rates and tectonic activity on the margins of the Australian Plate that were attributable to subduction of the Pacific plate beneath the Australian plate (Alexander et al. 1996; Draper, 2002).

\section{I The Jurassic Succession of the Eromanga Basin}

The Jurassic succession of the Eromanga Basin is of stratigraphic importance as it is where the extrusive igneous rocks documented within this study are believed to be located. Much of the 
Jurassic strata in the Eromanga Basin consists of predominantly quartzose fluviatile sandstones with subordinate shales and some coals (Senior et al., 1978; Exon \& Burger, 198I; Draper 2002). Sediments in the Eromanga Basin can be divided into three packages of decreasing age; lower non-marine, marine and upper non-marine. The focus of this study is the lower nonmarine package that was deposited between the early Jurassic ( $206 \mathrm{Ma})$ and the early Cretaceous ( 119 Ma) (Fig. 2). During this time, large sand-dominated, braided fluvial systems drained into lowland lakes and swamps. Throughout deposition, it is believed that sediment supply was a competing product of input from arc volcanism to the east, and sediment sourced from stable cratonic regions to the south (Boult et al., 1997). In the next part of this paper we detail the Early to Late Jurassic stratigraphy in order to provide a palaeogeographic framework for the study. The stratigraphic framework of the Jurassic succession has been iterated considerably in the last 20 years, evidenced by the progression of Alexander \& Hiburt's stratigraphic ages (1996) to Reid et al.'s (2009), to those listed on the Australian Stratigraphic Units Database (Geoscience Australia, 2017). For each formation we have used the most up-to-date reference available.

\section{I.I Poolowanna Formation, Early Jurassic, $200-178 \mathrm{Ma}$}

In southwest Queensland, the Poolowanna Fm. sits unconformably on top of the Late Triassic unconformity, which formed as a result of uplifting, tilting and erosion of the Cooper Basin at the end of the Early to Middle Triassic (Fig. 5). The palaeotopography of this unconformity strongly controlled deposition of the Poolowanna Formation and the subsequent Hutton Sandstone (Hall et al., 2015). Lithologies consist of coal and silt deposited in a highly sinuous fluvial setting with minor coal swamps (Hall, 20I5).

\section{I.2 Hutton Sandstone, Early to Middle Jurassic, I 78-166 Ma}

The Hutton Sandstone is a high energy braided fluvial Jurassic sandstone that either sits conformably on top of the Poolowanna Fm. or, where the Poolowanna is not present, unconformably above Triassic sediments (Kapel, 1966; Watts, 1987). The Hutton Sandstone is a mineralogically mature fine to coarse-grained sandstone with minor siltstone interbeds (Hall et al., 20I5). Throughout much of the Great Artesian Basin, the Hutton is a regional aquifer extending over an area of 1.7 million $\mathrm{km}^{2}$ (Hamilton et al. 1998). Similarly, the Hutton is the main reservoir within the Jurassic succession of the Eromanga Basin. 


\section{I.3 Birkhead Formation, Middle to Upper Jurassic, I66-160 Ma}

The boundary between the Hutton and Birkhead formations is sharp to transitional across the Eromanga Basin (Lanzilli, 1999) and is associated with a change in the depositional setting from the high energy, braided fluvial setting of the Hutton Sandstone to a low energy, fluvialdeltaic to deltaic and lacustrine setting in the Birkhead Formation (Watts, 1987; Lanzilli, 1999). This decrease is depositional energy is also associated with a change in sediment provenance from craton-derived sediment to lithic-rich, volcanogenic sediment from a proposed volcanic arc situated to the east above the subducting Pacific plate (Lanzilli, 1999). The diachronous influx of volcanogenic sediments can be traced across the Eromanga Basin (Boult, 1997). It is commonly picked as the top of the porous unit in the Hutton Sandstone (Paton, 1986; Watts, 1987), however, it can also be identified by the influx of lithic rich sandstones (Watts, 1987). There are several key features associated with the sediments shed from the volcanic arc (Patton, 1986):

- $50 \%$ quartz with high amounts of potassium and plagioclase feldspar. Trace amounts of tourmaline, pyroxene, mica and zircon were also noted (Watts, 1987; Alexander and Sansome, 1996).

- Lithic fragments mostly consisting of labile minerals.

- Common altering of the above lithics to kaolinite and chlorite or replacement of carbonate cements such as siderite or dolomite.

- Rare glassy fragments.

Based on the lithology of the volcanogenic sediments, it has been concluded that the volcanics that formed them were of acid to intermediate affinity (Patton, 1986). The influx of volcanogenic sediments is believed to have been controlled by the margin above the subducting pacific plate (Boult et al., 1998). During the Jurassic it is suggested that subduction of the Pacific plate beneath Australia caused extensive arc volcanism (Tucker et al., 2016). When uplift in this area was greatest, volcanogenic sediments were shed into the Eromanga Basin (Boult et al., 1997). Volcanogenic sediment in the Birkhead Fm. often forms a weak link with lower sealing capacity within what is the main sealing lithology for the Hutton Sandstone (Boult et al, 1997). 


\section{I.4 Adori Sandstone, Upper Jurassic, 160-I55 Ma}

The Birkhead Formation is capped by the Adori Sandstone, marked by a transition to clean, non-volcanogenic sedimentation. The Adori Sandstone is a well sorted and typically cross bedded, fine to coarse-grained sandstone (Hibburt, PGSA). It is interpreted to have been deposited in a low sinuosity fluvial system consisting of channel, point bar and flood plain deposits in the Central Eromanga Basin (Burger \& Senior, 1975; Hibburt, PGSA). Due to the absence of igneous rocks in the Mesozoic to Cenozoic succession younger than the Adori, the succession is not discussed in detail here.

\subsection{Structural Setting of the Study Area}

Structurally, the Cooper Basin can be divided into southern and northern sections (Gravestock \& Jensen-Schmidt, 1998; Hall, 2016). To the north, depocentres are dominantly Triassic, with Permian depocentres in the south (Hall et al., 2018). The northern and southern sections of the Cooper Basin are separated by the Jackson-Naccowlah-Pepita Trend (JNP trend) (Fig. I). In the south west, depocentres are generally thicker, reaching a maximum thickness of $2400 \mathrm{~m}$ in the Nappamerri Trough (Hall et al., 2015) and many of these depocentres have experienced synclinal folding due to differential compaction (Apak, 1997). The major depocentres are separated by northeast-southwest trending ridges (Gravestock \& Jensen Schmidt, 1998).

The area of focus in this study is the eastern Nappamerri Trough of north east South Australia and south west Queensland. The Nappamerri Trough contains the deepest basement within the Cooper Basin and hosts the Halifax well that intersected the deepest Permian-age sedimentary rocks in the basin at 4,209 $\mathrm{m}$ (Beach Energy, 20l3b). To the north, the Nappamerri Trough is bounded by the Gidgealpa, Canway, Packsaddle and Innamincka ridges (Fig. IA). The southern extent of the Nappamerri Trough is bounded by the DellaNappacoongee, Dunoon and Murteree ridges (Fig. I) (Hall, 20l6). The ridges bounding the northern and southern Nappamerri Trough are cored by deep thrust faults reactivated from pre-existing structures within the Warburton Basin (Robert et al., 1990). These were believed to have been reactivated in the Permian and the Cenozoic, when the Cooper and Eromanga Basins were subject to contractional deformation (Sun, 1997). 


\section{Methodology}

\section{I Identification of Volcanics Using Subsurface Data}

A number of volcanic features can be recognised using subsurface data. Here we describe the main techniques that were used to investigate igneous rocks within the Nappamerri Trough.

\section{I. I Seismic Data}

Seismic reflection is a geophysical technique that estimates properties of the earth's subsurface through the measurement of reflected seismic waves. It can be used to provide an estimate of the acoustic impedance of the boundaries to layers of rock within the subsurface (the product of the acoustic velocity and density of a rock). Seismic reflection data have been shown by numerous studies to be especially effective at imaging igneous rocks due to the high acoustic impedance of igneous material when compared to surrounding sedimentary rocks, and the distinctive morphology formed by lava flows and intrusions (Planke et al., 2000). Here we provide a brief introduction to the different types of igneous rock identified in the subsurface on seismic reflection data

Vents identified within seismic reflection data are typically grouped into either hydrothermal or volcanic vents (Reynolds et al., 2017). The morphologies of hydrothermal vents and volcanoes are similar as they both exhibit eye, dome or crater shaped morphologies in seismic data (Fig. 4B)(Planke et al., 2005; Grove, 2013; Reynolds et al., 2017). This can make distinguishing hydrothermal vents from volcanoes difficult when seismic reflection data are the sole data source.

Volcanoes can be confidently identified using seismic reflection data where they extend into lava flows (e.g. Fig. 4A-D). Lava flows are distinguishable as layer-parallel acoustically hard, bright reflectors within the subsurface (Planke et al., 2000; Schofield \& Jolley, 20 I3; Hardman et al., 20I8A) (Fig. 4B). Extrusive igneous rocks are distinguishable from intrusive igneous rocks as they do not transect stratigraphy.

Igneous intrusions have been studied intensely using 3D seismic data (Bell \& Butcher, 2002; Thomson \& Schofield, 2004; Archer et al., 2005; Magee et al., 2014). Igneous intrusions form acoustically hard, bright reflectors that are layer parallel or transect stratigraphy. In places, they can produce forced folding of the overburden with onlapping stratigraphy facilitating agedating of the intrusion (Trude et al., 2003). 


\section{I.2 Seismic Attributes}

3D seismic reflection data facilitates the analysis of the geophysical properties of igneous rocks in 3D. Seismic attributes such as RMS amplitude and spectral decomposition have proven to be effective tools in picking the extent and morphology of lava flows in seismic data (Fig.4C) (Schofield \& Jolley, 2013; Planke et al., 2017; Hardman et al., 2018A; Reynolds et al., 2018). Spectral decomposition involves filtering 3D seismic reflection wavelets to produce three amplitude components at distinct frequencies that are displayed as separate colour channels using the primary colours red, green and blue. These channels are then blended to produce full colour spectrum images where the igneous rocks appear visibly different to the surrounding sediments, due to their differing reflectiveness for particular frequencies (they transmit acoustic energy efficiently at all frequencies). Furthermore, this technique can be used to investigate the geometries of igneous rocks, and features such as inflation lobes (Fig. 8C) can help with distinguishing igneous intrusions from extrusive igneous rocks.

\section{I.3 Well Data}

In addition to the use of seismic data, the integrated analysis of borehole data including wireline log responses, core and cuttings is essential to accurately identifying igneous rocks within the subsurface (Nelson et al., 2009; Rider \& Kennedy, 20I I; Watson et al., 2017). The onshore response of igneous rocks in outcrop has been linked to offshore observations facilitating the identification of different volcanic facies through petrophysical and petrological analysis (Nelson et al., 2009; Millet et al., 2016).

Here, we use a combination of petrophysical and petrological data in our description of the WVP. Although cuttings and core were not examined within this study, descriptions were available within well reports that were integrated with petrophysical data and seismic reflection data to provide a comprehensive overview of the data available.

\subsection{Description of Dataset}

The Cooper and Eromanga Basins have been explored extensively over the past 60 years, so are characterised by the largest collection of well and seismic reflection data for any onshore sedimentary basin in Australia (Carr et al., 2016). A large database of seismic reflection data was available through Santos Limited and the Queensland Government's Department of Natural Resources and Mines. 3D and 2D seismic reflection surveys throughout the South Australian and Queensland sides of the basin were assessed for the presence of volcanic rocks 
(the extent of the seismic data examined is visible on Fig. IB). Notably, only four surveys available to this study (the Winnie 3D, the Gallus 2D, the Challum 3D and the Snowball 3D survey (provided by Santos Limited)), were interpreted to contain volcanic rocks. Unless stated, seismic data were displayed using normal (American) polarity, whereby a downward increase in acoustic impedance corresponds to a positive (blue) reflection and a downward decrease a negative (red) reflection.

Over 2000 wells have been drilled in the Cooper and Eromanga Basins. Despite this, of the wells available, only 3 (Lambda I, Orientos 2 and Kappa I) were identified as having intersected extrusive volcanic rocks with only I well (Warnie East I) encountering an intrusive igneous rock. The Warnie East I, Lambda I and Orientos 2 wells were key in constraining volcanism above the central Nappamerri Trough (Fig. IC). The Kappa I well was adjacent to the Snowball 3D survey, aiding interpretation of volcanism in the south west (Fig. IC). To estimate the relative age of the volcanic units, well data were tied, where possible, to the seismic reflection surveys available. For constraining the age of the Eromanga succession within the Central Nappamerri trough, the Halifax, Etty, Padme, Charal and Anakin wells were key (location on Fig. IC).

Here we present an overview of all the available datasets that constrain the distribution and age of igneous rocks within the study area. First, we detail the main WVP, within which the lithology and morphology of the igneous rocks appear broadly similar throughout the eastern Nappamerri Trough. We then deal with the Snowball 3D survey and the Kappa I well that image volcanic rocks that have a markedly different petrological and geophysical character when compared to the rest of the WVP. It is important we recognise that whilst this is the extent of the data that was available during this study, the authors are aware of other seismic reflection surveys within the Nappamerri Trough that were not available to download digitally and were not possible to acquire within the period of time during which this study was conducted. These surveys may also image igneous rocks that could fuel further work on the area. 


\section{Description of Igneous Rocks in Seismic Data within the eastern Nappamerri}

\section{Trough}

\section{I Winnie 3D}

The main 3D seismic reflection survey utilised within this study is the Winnie 3D survey. Acquired in 2012 by Drillsearch Energy Ltd. The survey was shot above the eastern Nappamerri Trough in southwest Queensland over an area of $2545 \mathrm{~km}^{2}$ (Fig. I). The main focus when acquiring the survey was on the unconventional targets in the area, typically the extensive Permian coal-rich source rocks (Hillis et al., 200I; Schmidt, 20I3). The dominant frequency within the Jurassic succession is $\sim 40 \mathrm{~Hz}$, with volcanic rocks in the region having an acoustic velocity of 4 to $6 \mathrm{kms}^{-1}$ (taken from the Lambda-I exploration well). Using an average velocity of $5 \mathrm{kms}^{-1}$ a vertical resolution of $\sim 30 \mathrm{~m}$ and a detection limit of $4 \mathrm{~m}$ was calculated.

\section{I.I Extrusive Igneous Rocks}

We identified $\sim 100,<=4 \mathrm{~km}^{2}$ cone shaped features that often express an eye-shaped morphology (Fig. 2B). The cones within the survey are less than $2 \mathrm{~km}$ long and $750 \mathrm{~m}$ wide, and often elongate in a NW-SE direction. We have interpreted these as monogenetic volcanoes, small cumulative volume volcanic edifices built up by one continuous, or many discontinuous, small eruptions over a short time scale $(<=10$ years) (Nemeth \& Kereszturi, 20I5).

Twelve of the volcanoes are linked with what appear to be elongate, NW-SE oriented lava flows that are conformable to stratigraphy and have dimensions of $2-7 \mathrm{~km}$ in length and 0.5-2.5 km in width (covering areas of $4-13.5 \mathrm{~km}^{2}$ ) (e.g. Fig. $6 \&$ 7). The flows appear to be strata-concordant and confined to the Hutton Sandstone or the base of the Birkhead Formation which would place the flows between 160 and 178 Ma (Alexander \& Hibburt, 1996) (Fig. 7).

We have also interpreted one feature within the survey as a diatreme. Maar-diatreme volcanism can occur where a volcanic pipe forms through gaseous explosions that cut into the country rock (Fig. $4 \mathrm{E}-\mathrm{H})$ (White \& Ross, 20I I). These explosions form a maar (the crater and associated ejecta ring) and a diatreme (the root to the maar), consisting of a steep-sided cone shaped structure filled with pyroclastic, volcanic and country rocks)(White \& Ross, 
20II). Unlike vents and associated lava flows, they consist of downward dipping reflectors that truncate the underlying stratigraphy with typically chaotic internal reflectors (Fig. 4F). Spectral decomposition proved to be the most powerful tool for identifying maar-diatremes above the Nappamerri Trough, as the circular crater morphology stood out against the surrounding sediments (Fig. 4G). One feature interpreted to be a diatreme was identified within the survey, displayed in detail in (Fig. 4). It is $\sim 2.25 \mathrm{~km}^{2}$ and $\sim 120 \mathrm{~m}$ deep (I50 ms, TWT) and is found in the west of the Winnie 3D survey (Fig. 6).

\section{I.2 Intrusive Igneous Rocks}

Igneous intrusions within the Winnie 3D survey are identified as igneous rocks that cross-cut the Triassic to Jurassic strata; notably the Nappamerri, Hutton and Birkhead Fms (e.g. Fig. 8A). We identified and mapped 14 intrusions in the seismic data; these occur $\sim 100$ $200 \mathrm{~ms}(\sim 105-210 \mathrm{~m})$ below the palaeosurface. Most of the sills identified are of a similar scale to the lava flows in the area $(2-4.5 \mathrm{~km}$ long, $1.2-1.7 \mathrm{~km}$ wide),

The Winnie 3D survey also hosts a spectacular single intrusion, $14 \mathrm{~km}$ long and $8 \mathrm{~km}$ wide, by far the largest igneous feature in the WVP (Fig. 8A \& B). Classical intrusion related features such as inflation lobes are observed within spectral decomposition (Fig. 8C). 20 vents cross-cut this intrusion (see pockmarks on Fig. $8 \mathrm{C}$ ), in places leading to extrusive lava flows in the overlying sediments (see surface flows on Top Birkhead overlying the intrusion in Fig. 8B). The presence of the pockmarks on the surface of the intrusion suggest emplacement of the sill predated a later stage of volcanism that occurred towards the top of the Birkhead Fm.

\section{I.3 Timing of Volcanism and Intrusion}

The timing of igneous activity within the Winnie 3D survey was constrained by the stratigraphic relationship between igneous activity and the Triassic to Jurassic stratigraphy in the study area. In places, intrusions are observed to have caused forced folding of the overburden, as evidenced by onlap of Birkhead Fm. sediments onto the deformed overburden overlying the intrusions (Fig. 8B). Onlap of sedimentary rocks onto these forced folds was used to age constrain the intrusion (Trude et al., 2003), whilst the strata-concordant surface flows were assigned an approximate age based on their stratigraphic level that was tied to known stratigraphy within the wells. We estimate that volcanism lasted throughout deposition of the Hutton and Birkhead formations between $\sim 178$ and $160 \mathrm{Ma}$, with the youngest 
volcanics identified as surface flows emplaced on the top Birkhead marker horizon (Alexander \& Hibburt, 1996).

\section{I.4 Basement Structure and Igneous Rock Distribution}

The basin structure of the eastern Nappamerri Trough is largely obscured by the thick Cooper and Eromanga Basin fill (the deepest Permian-age sedimentary rocks drilled in the basin are 4,209 m deep (Beach Energy, 20I3b)) and the highly reflective coals of the Permian Toolachee and Patchawarra Fms that make imaging of deeper sediments difficult. Of all the 3D seismic reflection surveys available for this study, only the Winnie 3D survey imaged reflections $\sim 2800 \mathrm{~ms}$ deep within the Nappamerri Trough (approximately $4.3 \mathrm{~km}$ subsurface depth based on the Charal-I time-depth relationship). Notably, the exact lithology of this reflection is unclear, largely due to the lack of any intersections in the Central Nappameri wells. Unlike the flat-lying Cooper and Eromanga stratigraphy, these deep reflections were often inclined at an angle of $\sim 10^{\circ}$ (taken with the scale set so that Is TWT depth $=1 \mathrm{~km}$ distance laterally). Although not confidently picked throughout the whole of the Winnie 3D survey, the reflections can be mapped over an area of $\sim 600 \mathrm{~km}^{2}$ (Fig. 9C). We interpret these to represent the top Basement in the Nappamerri Trough.

In places, the reflections are visibly offset on the order of $\sim 100 \mathrm{~ms}$ (Fig. 9A). When mapped and in plan view, it is clear that the most major offset (a $\sim 400 \mathrm{~ms}$ step in the data visible in

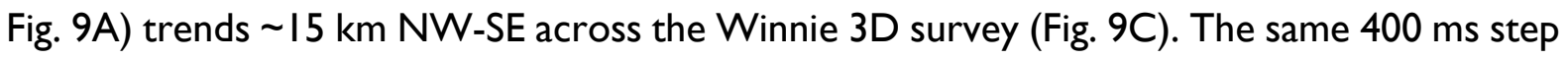
has been noted by previous mapping (NGMA, 2003) where it is visible on a top basement map in the eastern Nappamerri Trough. We interpret offset of the top basement as faulting and, so that it may be easily referred to throughout the text, name the major $400 \mathrm{~ms}$ offset the Central Nappamerri Fault.

Beneath the vents and volcanoes of the Winnie 3D survey, the seismic reflection data exhibited a velocity pull-up effect, where reflection events directly beneath the vents were pulled up in two-way time relative to the surrounding area (Fig. 9A). This could either represent shallow high velocity material (i.e., the vents or volcanoes themselves) or a high velocity feeder zone representing a vertical column of igneous rock or hydrothermally altered host rock. This effect was particularly obvious on the well-imaged Toolachee Fm. and, hence, the Toolachee Fm. was mapped in order to better constrain the distribution of the pull-up effects throughout the area (Fig. 9C). Here, the distorted zones are imaged as dark patches that are clearly distinguished from the fluvial channels that make up the Toolachee Fm. (Fig. 
9C). We have interpreted these as vents that are either hydrothermal vents or basaltic dykes. The position of these vents was highlighted and superimposed on top of an image of the basement reflections (Fig. 9C). The vents broadly fall into two groups, one to the SW of the Central Nappamerri Fault and one to the NE of the Central Nappamerri Fault. These groups fall adjacent to the Top Basement reflections or directly above visible offset in the basement, strongly implying a pervasive structural control on the location of vents in the Winnie 3D survey.

\subsection{Gallus 2D}

The Gallus 2D seismic reflection dataset was shot in 2013 by Beach Energy. The survey covers $420 \mathrm{~km}^{2}$ of the Nappamerri Trough, to the north of the Winnie 3D survey (Fig. II). It was used to constrain the northern extent of the WVP. Although a dominant frequency of $\sim 35$ $\mathrm{Hz}$ and average velocity of $5 \mathrm{kms}^{-1}$ for the igneous rocks in the area suggests a vertical resolution of $\sim 40 \mathrm{~m}$ and a detection limit of $5.5 \mathrm{~m}$, imaging was generally poorer than that of the Winnie 3D survey. This was probably due to the inferior signal-to-noise ratio of stacked 2D seismic reflection data by comparison with that of an equivalent section line extracted from stacked 3D data. In particular, the 2D nature of the survey and, hence, the inability to conduct attribute analysis made the mapping of igneous rocks difficult.

A northwards continuation of the monogenetic vents, flows and intrusions that were detailed in the Winnie 3D survey is imaged within the Gallus 2D survey (Fig. IIA-C). In order to better constrain the distribution of the volcanics in the Gallus 2D survey, the top and bottom of the igneous rocks were mapped. From these, we calculated the isochron thickness of the igneous rocks in the area (Fig. IIA). Like the Winnie 3D survey, volcanism was more pervasive towards the east, with the thickest volcanics ( $\sim 300 \mathrm{~ms}$, approximately $163 \mathrm{~m}$ ) located at the eastern edge of the survey. Whilst none of the volcanics were intersected by any wells, the approximate stratigraphic age was constrained by the nearby Halifax and Etty wells (Fig. IIC), placing the volcanics within the Hutton and Birkhead formations, as found for the Winnie 3D survey.

\subsection{Madigan 3D}

The Madigan 3D seismic reflection survey was shot in 1996 by Santos Ltd. The Madigan 3D survey covers an area of $584 \mathrm{~km}^{2}$ over the Challum Field, which consists of gas reserves hosted within the Toolachee Formation and pre-Permian carbonates (Yew \& Mills, 1989)(Fig. 
10). The survey is situated across the very north eastern edge of the Nappamerri Trough, above the JNP trend, adjacent to the confluence point of the JNP trend and the Innamincka Ridge. The dominant frequency within the Jurassic succession was $\sim 35 \mathrm{~Hz}$, and using an average velocity of $5 \mathrm{kms}^{-1}$ a vertical resolution of $\sim 35 \mathrm{~m}$ and a detection limit of $5 \mathrm{~m}$ was calculated.

Two vents were identified within the seismic data that consisted of a single positive amplitude reflection (Fig. 10). The smaller vent $(750 \mathrm{~m} \times 1.5 \mathrm{~km})$ is situated directly above the JNP trend. The second is $\sim 5 \mathrm{~km}$ to the SW and larger, at $1.5 \mathrm{~km} \times 1.5 \mathrm{~km}$, with a central $500 \mathrm{~m}$ depression interpreted to be a central crater (Fig. 10). RMS amplitude extraction reveals the central crater of both vents (Fig. 10). As neither vent was penetrated by a well and no surface flows were mapped away from the vents, it cannot be concluded whether they are volcanic or hydrothermal. Stratigraphic data from the neighbouring Challum wells were used to constrain a rough stratigraphic age for the vents, placing them towards the base of the Hutton Sandstone ( 178-200 Ma). It is unclear on the basis of the 3D seismic reflection data what the age of these vents is. They appear to sit near the top of the Nappamerri Group, however, this would place them in the middle Triassic $\sim 240 \mathrm{Ma}, \sim 60$ Myrs older than the rest of the WVP. An alternative explanation would be the emplacement of these vents at the very base of the Jurassic in this region (a maximum age of $\sim 200 \mathrm{Ma}$, Fig. 2), as they appear to cross-cut all of the Triassic Nappamerri Group stratigraphy. This second explanation is preferable as it would fit with the proposed age for the rest of the WVP.

\section{Description of Igneous Rocks in Well Data within the Eastern Nappamerri}

\section{Trough}

\section{I Extrusive Igneous Rocks}

\section{I.I Lambda I}

The Lambda I well was drilled in 1984 by Delhi Petroleum Pty. Ltd. At a depth of 1570.9 m, $283 \mathrm{~m}$ of igneous rocks were intersected, directly underlying the base of the Birkhead Fm. (Fig. 12). The upper $33 \mathrm{~m}$ of basalt are heavily weathered, fractured and vesicular, as noted in the Lambda well report (Short, 1984). This is represented by poor seismic imaging due to the low density and acoustic velocity of the upper $33 \mathrm{~m}$ relative to the rest of the volcanic succession (Fig. 12A). The remaining $250 \mathrm{~m}$ of basalt is fresh and crystalline. It typically has 
low gamma ray values, with consistently high density and acoustic velocity (Fig. I2A). There are localised areas where the density drops drastically, however, these are associated with increases in the caliper and may therefore point to caving of the wellbore when it was drilled or fractures within the basalt, rather than lithological variations. At the base of the basalt $\sim 1.5$ $\mathrm{m}$ of core was cut, within which the fine grained, crystalline nature of the basalt is apparent (Fig. I2A, see picture).

Interval velocity histograms were created for the Lambda I volcanics. They were then binned with a bin spacing of $0.125 \mathrm{~m}$ order to create a velocity histogram (Fig. 12C). These were superimposed on the velocity histogram fields of Nelson et al., (2009) that were obtained from boreholes on the Faroe Islands in the North Atlantic in order to compare the acoustic velocities of igneous rocks in the Nappamerri Trough with values from elsewhere. It can be seen in Fig. I2C that the Lambda I volcanics show a very strong similarity to the tabular basalt analysed by Nelson et al. (2009).

Additionally, vitrinite reflectance data (Boothby, 1986) were available for sediments deposited on top of the Lambda-I volcanics (Fig. 12B). Notably, in the sediment contact with the volcanics, there is no deviation towards high \%RoMax, suggesting that the Lambda I volcanics had little thermal effect on the overlying organic matter. If this were an intrusion, it is expected that the VR values would be elevated (Stewart et al., 2005) and the absence of such elevated values implies that the basalt is extrusive.

$\mathrm{K}-\mathrm{Ar}$ dating was conducted on a bag of drill cuttings taken from a depth of $1658 \mathrm{~m}$. Although the samples were too altered to be used for total rock analysis, fresh plagioclase within the cuttings was separated for analysis and used to determine an age of $227+/$ - $3 \mathrm{Ma}$, suggesting emplacement of the basalt during the early Triassic (Murray, 1994). However, in Lambda-I, the basalt is situated between the Jurassic Birkhead Fm. and the Triassic Nappamerri Gp., supporting a Late Triassic to Jurassic age (Draper, 2002). K-Ar dating of basaltic volcanic rocks is often unreliable (Schofield et al., 20I5), due to unquantified argon loss (Kelley, 2002). It is noted within the well report that the loss of Argon due to subsequent thermal events or contamination of drill cuttings is not accounted for in the quoted error (Murray, 1994). In combination with the extensive seismic evidence for Middle to Late Jurassic age volcanics, we deem a Jurassic age of eruption most likely.

\section{D Seismic across the Lambda I well}


A single 2D seismic line intersecting the Lambda I well was available (Fig. I3). Within the 2D line, the tabular basalt intersected by the Lambda I well corresponds to a high amplitude reflection most pronounced at the location of the well but also continuing $\sim 3 \mathrm{~km}$ to the west of the survey. The centre of the survey (and the location of the well) corresponds with a $\sim 1.5$ $\mathrm{km}$ wide anticline that exhibits doming on the order of $\sim 150 \mathrm{~ms}$. Below the anticline and the location of the volcanics, the 2D seismic reflections are visibly distorted, being most pronounced beneath the location of the well where a velocity pull-up effect, similar to those observed below the igneous rocks in the Winnie 3D survey, is visible. We interpret the Lambda I volcanics to be a central vent drilled by the well, with a lava flow extending $3 \mathrm{~km}$ to the west of the survey.

Stratigraphically, the Birkhead Fm. extends across the whole survey, however, the Hutton Sandstone and equivalent sediments (not penetrated by the Lambda I well) are seen to onlap the Lambda I volcanics. The lava flow extending away from Lambda I sits atop Triassic Nappamerri Group sediments of the Cooper Basin whereas the volcanics penetrated by Lambda I appear to cross cut the Triassic stratigraphy. In combination with the well data, we believe a Hutton to Birkhead Fm. age (I78 - I63 Ma) for the volcanics to be most likely, although we cannot discount that some of the volcanics may be Late Triassic in age.

\subsubsection{Orientos 2}

Similarly to Lambda I, Orientos 2 drilled through volcanics situated at $1555 \mathrm{~m}$, beneath the Jurassic age Adori Sandstone (Fig. 14). The well drilled through $34 \mathrm{~m}$ of volcanics before drilling was ceased, before reaching the base of the volcanics. The volcanics are described as dark green, grey black with quartz inclusions and common amphiboles. Similar to the Lambda I well, Orientos 2 also encountered $\sim 14 \mathrm{~m}$ of chloritic, weathered basalt identifiable by low density and sonic values at the top of the volcanic succession and by the cuttings described in the end-of-well report (Bucknill, 1990). Draper (2002) noted that Orientos 2 was drilled <1 $\mathrm{km}$ from Orientos I, which did not intersect basalt, suggesting that the basalt In Orientos 2 might be intrusive in origin. However, we note that the Padme, Anakin and Charal wells were all drilled less than 2-5 km from what appear to be extrusive volcanics identified in the Winnie 3D survey, but due to the localised nature of the volcanics, they are not noted in any of the well logs. As such, we do not take the absence of volcanics in Orientos I to be indicative of an intrusive origin for the Orientos 2 volcanics. Due to the similarity in their log signature and 
the lithological information recorded in the end-of-well report (Bucknill, 1990), we believe Orientos 2 drilled through a series of Jurassic-aged extrusive basalts.

\section{D Seismic across the Orientos 2 well}

A single 2D seismic reflection survey line running south to north across the Orientos 2 well path was available. High amplitude reflections running across the survey appear similar to the extrusive volcanics interpreted in the Winnie 3D survey, with a $\sim \mathrm{l} \mathrm{km}$ reflection penetrated by Orientos 2 and a $\sim 4 \mathrm{~km}$ reflection $\sim 100 \mathrm{~m}$ to the north of the Orientos 2 reflection. Like the Lambda I volcanics, we interpreted these to be two lava flows, although vents visible below the flows suggest these flows may be made up of multiple eruptions.

Stratigraphically the flows sit on top of the Triassic Nappamerri Group and are onlapped and age equivalent to the Birkhead and Hutton Sandstone formations (178 - $160 \mathrm{ma}$ ). However, the northernmost vent and the Orientos 2 vent are situated directly below the Adori Sandstone raising the possibility of some volcanic rocks in the area that are younger than 160 Ma.

\subsection{Intrusive Igneous Rocks}

\subsection{Warnie East I}

Igneous rocks intersected within the Warnie East I well are lithologically unique amongst the igneous rocks penetrated by wells in the WVP. Located at $2103 \mathrm{~m}$ depth within the Permian Toolachee $\mathrm{Fm}$, the $65 \mathrm{~m}$ thick basalt is fine grained and dominated by plagioclase laths intergrown with augite (Fig. 16). The upper $12 \mathrm{~m}$ of the volcanics appear altered and calcareous, containing phenocrysts of augite with minor pale green talc and minor calcite veining (Boothby, 1986).

The age of the igneous rocks is unclear based on available data. Palaynological data indicates that sedimentary rocks immediately overlying igneous rocks in the Warnie East I well are Permian in age (belonging to the Toolachee Fm.). Furthermore, sedimentary rocks below the basalt to $2228 \mathrm{~m}$ are barren of palynological data. Like Lambda- I, K-Ar dating was conducted on a sample of drill core from $2163 \mathrm{~m}$ (Murray, 1994). Again, the rock was too altered to be used for whole rock K-Ar and, instead, unaltered pyroxene was used for dating. A middle Cretaceous age of $100 \pm 9$ Ma was calculated (Murray, 1994), significantly younger than the rest of the WVP and the Permian host rock within which the intrusion is located. Draper 
519 (2002) found the age dating to be 'equivocal' due to the large difference in age for the Lambda520 I extrusive basalt (227 $\pm 3 \mathrm{Ma})$ and the Warnie East intrusive basalt ( $100 \pm 9 \mathrm{Ma})$ (ages from 521 Murray, 1994). It is therefore important consider the K-Ar ages and the stratigraphical 522 position of the igneous rocks with respect to other data.

523 Vitrinite reflectance data were acquired within the Warnie East I well. (Fig. I6B). Samples of 524 vitrain were obtained and mean maximum reflectance of vitrinite calculated (Smith, 1987). 525 Vitrinite reflectance samples adjacent (directly above and below) to the basalt show a marked 526 increase to $4.5 \%$ relative to surrounding Toolachee sediments that are typically $1.5-1.75 \%$ (Fig. 527 16). Whereas extrusive volcanics appear to have little thermal effect on the surrounding 528 sediments (e.g. Grove, 20I4), igneous intrusions typically show uniform heating on either side 529 of the volcanics, as is observed here. Coupled with its stratigraphic position within the 530 Toolachee Fm., where no other volcanics have been documented within the Cooper Basin, 531 we conclude that Warnie East I contains the sole identified intersection of an intrusion in the 532 WVP.

\section{2D Seismic across the Warnie East I well}

534 As with the previous two wells, a 2D seismic reflection survey line runs across the Warnie East well (Fig. 17). Unlike the Lambda I and Orientos 2 volcanics, the igneous rocks within the Warnie East I well sit within the Toolachee Fm., a highly reflective sequence of heterogeneous lithologies consisting of sandstones, siltstones and coals. As such, the igneous rocks are difficult to distinguish on seismic reflection survey data, although a shallow saucershaped reflection intersects the well path of the Warnie East I well at the depth that igneous rocks are located. The reflection is $\sim 1.5 \mathrm{~km}$ wide and transects the Toolachee Fm. over a depth range of $50 \mathrm{~ms}$. The shallow saucer shape that the reflection event exhibits is common among igneous intrusions within sedimentary basins, corroborating the well data that suggests the igneous rocks are intrusive in nature.

6. Description of Anomalous Igneous Rocks within the southern Nappamerri

546 Trough

547 This study has so far dealt with igneous rocks of a very consistent lithology preserved within or above the Central Nappamerri Trough. However, the Kappa I well and Snowball 3D 
seismic reflection survey, located on the very southern edge of the mapped extent of the WVP, preserve igneous rocks of a very different character (Figs. 18 -20).

\section{I Kappa I Well}

The Kappa I well was drilled in 1997 on behalf of Santos Limited (Allen, 1998). The aim of the well was to evaluate the Toolachee, Patchawarra and Epsilon formations (Allen, 1998). Kappa $\mathrm{I}$ is located above a large anticline and is the southernmost of a string of prospects located above the Kinta structural trend, which deepens northwards into the Nappamerri Trough (Fig. I)(Allen, 1998). Between 1895 and 2115 m, the Kappa well intersected a $120 \mathrm{~m}$ thick succession of volcanics below a thinned 21 m succession of Hutton Sandstone (Fig. I8). Within the well report, the volcanics are ascribed a late Permian to Middle Triassic age (Allen, 1998).

The primary lithological information for the volcanics comes from assorted rock chips and cuttings. Due to the large amount of alteration, the volcanics appear as a chloritized basalt with abundant plagioclase, chlorite, carbonates and quartz (Allen, 1998). The rock is mottled and light green to a reddish brown colour (Allen, 1998). However, some variation was noted. Firstly, a vesicular microporphyritic basalt was identified that consisted of olivine and pyroxene phenocrysts contained within a fine grained or glassy groundmass (Allen, 1998). Secondly, less abundant coarse grained holocrystalline basalt that was composed of randomly oriented plagioclase laths, ferromagnesian crystals and accessory magnetite plus ilmenite (Allen, 1998). Importantly, and pervasively throughout the succession, a fibrous chlorite has replaced much of the ferromagnesian minerals and groundmass as well rimming and filling vesicles within the basalt (Allen, 1998).

The Igneous succession in Kappa I also has an unusual petrophysical expression. In our interpretation, we have divided the volcanics into two facies; in situ basalt and a volcaniclastic breccia (Fig. 18). The in situ basalt (e.g. the section between $1900 \mathrm{~m}$ and $1960 \mathrm{~m}$ (Fig. 18)) has a 'saw-tooth' response with a relatively low gamma response of $\sim 40$. Acoustic velocities from the sonic velocity log $\left(\sim 4 \mathrm{kms}^{-1}\right)$ are consistently lower than those observed in the Lambda I and Orientos 2 wells $\left(\sim 5.5-6 \mathrm{kms}^{-1}\right)$. The chaotic, saw-tooth response is indicative of the highly altered nature of the volcanic succession in Kappa I and the compound nature of the lava flows (Millet et al., 2015; Hardman et al., 2018a) (Fig. 18). The resistivity throughout the section interpreted to be in situ volcanics consistently measures I5 $\Omega \mathrm{m}$. As with the Lambda 
580

581

582

583

584

585

586

587

588

589

590

591

592

593

594

595

596

597

598

599

600

601

602

603

604

605

606

607

608

609

610

well, we constructed a velocity histogram for the igneous rocks in the Kappa I well. When compared to Nelson et al.'s velocity histograms (2009) the best match was with that of Compound-braided flows (Fig. 18).

The volcaniclastic breccia typically consists of poorly sorted, subangular, volcaniclastic igneous rock of very fine sand to granule size (Allen, 1998). The log response for the volcaniclastic breccia is characterised by a jagged petrophysical response when compared to the in situ basalt. Although the gamma ray values ( $\sim 40 \mathrm{api}$ ) are similar to those of the in situ basalt, the acoustic velocities (between 2800 and $4 \mathrm{kms}^{-1}$ ) are consistently lower. Furthermore, the volcaniclastic breccia is water saturated with a resistivity of $2-3 \Omega \mathrm{m}$, although this may also be a reflection of the magnetite and ilmenite within the basalt. Finally, below $2050 \mathrm{~m}$ to the base of the volcanic succession, the Caliper tool widened significantly suggesting the volcaniclastics in this part of the succession are considerably unconsolidated and/or fractured.

\subsection{Snowball 3D Seismic Survey}

The Snowball 3D seismic reflection survey is situated $\sim 5 \mathrm{~km}$ south of the southwest tip of the Winnie 3D survey, on the border of Queensland and South Australia. Unfortunately, the Kappa I well is located $\sim 2 \mathrm{~km}$ outside of the Snowball 3D survey data that was available to used within this study. Furthermore, no sonic velocity data were acquired for the Kappa I well. In order to tie this well to the Snowball 3D survey, a pseudo TWT/depth plot was created using the velocity data synthesised for the wells drilling within the central Nappamerri Trough (Fig. 19)(Halifax, Etty, Anakin, Padme, Charal).

The Snowball 3D seismic reflection data are displayed such that a downward increase in acoustic impedance corresponded to a red, negative reflection (European polarity). The dominant frequency within the Jurassic succession was $\sim 35 \mathrm{~Hz}$, however, the average velocity of the igneous rocks in the Kappa I survey was $4 \mathrm{kms}^{-1}$, lower than the other igneous rocks in the WVP. Hence, a higher than average vertical resolution (lower resolvable thickness) of $\sim 29 \mathrm{~m}$ and a detection limit of $4 \mathrm{~m}$ were calculated.

The top of the Kappa I volcanics is interpreted to correlate with a bright, laterally continuous red reflection that was present across the whole of the Snowball 3D survey (Figs. $19 \& 20$ ). Above the top Kappa I volcanics a second reflector, deemed here the 'Top Volcanic Mounds,' was mapped in parts of the Snowball 3D survey adjacent to a series of mound-like structures, appearing in places to downlap onto the top Kappa I volcanics (Fig. 20). The centres of these- 
mound shaped structures are marked by a notable brightening of the reflector that is underlain by vertical vents similar to those seen in the other surveys. We thus interpret these mound structures to be a series of volcanic edifices.

The volcanics interpreted to be present in the Snowball 3D survey are notably different to those preserved in the Nappamerri Trough (e.g. Figs 7-9). Rather than isolated, monogenetic vents or flows, they are interpreted to represent a thick package (up to $\sim 150 \mathrm{~ms}$ ) of mixed volcanics and volcaniclastic breccias (based on evidence from Kappa-I) that thin towards the southwest of the survey (Fig. 20A) (i.e. the southern edge of the Nappamerri Trough). Although the true extent of them is not imaged within the survey (they are interpreted to extend beyond the survey limits), laterally they extend over $6 \mathrm{~km}$. Spectral decomposition was used to gain a better understanding of these volcanics in 3D (Fig. 20C). We found darker colours surrounding the vents with these colours interpreted to represent the extent of the lava flow fields.

\subsection{Interpretation of Snowball Volcanics}

The volcanic succession is described as pyroclastic in the Kappa-I well report. Whilst this interpretation can account for some of the altered volcaniclastics, it does not explain the extensive sequence of altered basalt. An alternative explanation for the extensive sequence of altered basalt is differing sedimentation and eruption rates within the Eromanga succession deposited above the Nappamerri Trough. However, Mid-Late Jurassic sedimentation rates at Kappa-I of 2.4 m.my ${ }^{-1}$ (calculated by dividing the thickness of the Hutton to Adori succession by a duration of 23 Myrs) do not appear materially different to those in the Warnie or Lambda wells ( 2.8 and $2.5 \mathrm{~m} . \mathrm{my}^{-1}$ respectively). Hence, alteration does not appear to be a consequence of extensive surface exposure.

A more compelling explanation for the Kappa I volcanics is hydrothermal alteration. In volcanic regions, many lakes are typically fed by hot springs. In the East African Rift, discharge of hydrothermal water can produce authigenic chlorite with calcite and quartz forming pore filling cements (Renaut et al., 2002). These minerals, particularly chlorite, are noted extensively within the petrological description of the Kappa I well. Additionally, the Kappa I well lies above the Kinta structural trend which could have provided a pathway for hydrothermal fluids into the Eromanga succession (Kulikowski et al., 2015). Basin-wide hydrothermal fluid circulation has been noted within the Cooper Basin (Zwingmann et al., 200I; Middleton et al., 
20I4, 20I5). In the Nappamerri Trough, these fluids are believed to have formed due to rifting of the eastern Australian margin during the mid-Cretaceous (Middleton, 2015). We propose that the Kappa I well represents a succession of volcaniclastic and primary volcanic rocks that was highly altered by hydrothermal fluids.

\section{Airborne Geophysical Surveys of the Nappamerri Trough}

\section{I Gravity Data}

Alongside seismic and well data, airborne geophysical surveys were examined in order to further delineate the regional distribution of the WVP (Fig. 2IA). The gravity data in this study were adopted from Tracey \& Bacchin (2008). In southern Queensland, the Nappamerri Trough is typically characterized by a broad gravity low. However, a pronounced $\sim 50 \times 50$ km gravity high is apparent in the northeast Nappamerri Trough (Fig. IB). Gravity modelling of the Cooper Basin suggests that localised gravity lows adjacent to the $50 \times 50 \mathrm{~km}$ high within the Nappamerri Trough are the result of low density granites and granodiorites within the basement (Meixner et al., 20I2). Furthermore, the quantity of mapped intrusive and extrusive volcanics increases towards the centre of the $50 \times 50 \mathrm{~km}$ gravity anomaly (Fig. IB). We interpret the $50 \times 50 \mathrm{~km}$ gravity anomaly to represent an expression of the WVP, as it highlights an increase in the volume of igneous rocks towards the centre of the Nappamerri Trough and perhaps also a weak point between granitic bodies that facilitated the transport of magma into the Eromanga succession. Our lack of constraint on the exact size of the WVP means we cannot confirm that the thickness and areal extent of the igneous rocks are sufficient to produce the size of the gravity anomaly observed in the Nappamerri Trough.

\subsection{Magnetic Data}

In addition to gravity data, a total magnetic intensity survey has been analysed (Fig. 22). Previous investigations of magnetic anomalies in the Cooper Basin by Meixner et al. (2000) have concluded that the sources of magnetic anomalies all occur at or below the base of the Cooper Basin succession, due to the absence of any significant magnetic sources within the sedimentary sequences of the Cooper and Eromanga basins. The Nappamerri Trough is generally marked by a low in the magnetic intensity whilst the bounding ridges are magnetic highs. However, a $\sim 75 \times 40$ km magnetic intensity high runs from the Innamincka Ridge across the northern extent of the WVP in a NW-SE direction, with many smaller ( $<8 \mathrm{~km}^{2}$ anomalies) scattered throughout the Nappamerri Trough (Fig. 22A-D). Basalt is highly susceptible to 
being magnetised (Tarling, 1966), which has facilitated the recognition of buried volcanic rocks elsewhere in the world (Segawa et al., 1975). Notably, many of the smaller magnetic anomalies do crudely correspond to the location of lava flows in the Winnie 3D survey (Fig. 22D). However, the large $75 \times 40 \mathrm{~km}$ anomaly does not correspond with extrusive igneous rocks, otherwise this would have been imaged in the northern Gallus 2D lines. Without good seismic imaging below the Cooper Basin sediments, or boreholes that drill down through the entire Cooper Basin succession, it is difficult to confidently identify what this magnetic anomaly represents. We postulate that this could be an expression of the plumbing system of the WVP, although this is highly speculative. If true, it could point to an extensive network of igneous intrusions that are not imaged by available data.

\section{Discussion}

\section{I The Age of the Warnie Volcanic Province}

Within this manuscript we have detailed the rough age of igneous rocks within the Cooper and Eromanga basins. Here we synthesise the different methods used to define an age range for the eruption of the igneous rocks.

$\mathrm{K}-\mathrm{Ar}$ dating was conducted on both the Lambda I extrusive basalt and the Warnie East lintrusive basalt deducing an age of $227 \pm 3$ and $100 \pm 9$ Ma, respectively (Murray 1994). However, the large differences in age for these igneous rocks led Draper (2002) to question the validity of the results suggesting they were "equivocal." Furthermore, Murray (1994) noted that loss of argon due to subsequent thermal events was not accounted for in the quoted error of the ages. K-Ar dating has been shown to be unreliable due to unquantified argon loss (Kelley, 2002; Schofield et al., 2015) and in combination with the altered lithology of many of the igneous rocks within the Warnie Volcanic Province (Murray, 1994) we cannot consider the $\mathrm{K}-\mathrm{Ar}$ dating to be reliable in the absence of further evidence for the age of these rocks.

Stratigraphically, all the extrusive igneous rocks analysed within well data are situated between Jurassic sedimentary rocks (the Hutton and Birkhead fms.) and the Triassic Nappamerri Group. which supports a late Triassic to Jurassic age (Draper, 2002). The corroboration of well data with $3 \mathrm{D}$ seismic reflection data has allowed us to define further intrusive and extrusive volcanic events that are strata-concordant with the Birkhead Fm. and Hutton Sandstone, placing them between $\sim 178$ and I60 Ma. The oldest extrusive volcanics identified 
using 3D seismic reflection data are the vents within the northern Challum 3D survey that appear to sit near the top of the Nappamerri Group below the Hutton Sandstone. This could extend the age of the Warnie Volcanic Province into the Triassic which would agree with the K-Ar dating for the Lambda I well. Equally, the vents could be interpreted as cross-cutting the Triassic strata which would give them an Early Jurassic age. In the absence of further data, their exact age is unclear.

We conclude that the vast majority of igneous rocks identified using 3D seismic reflection data and well data throughout this study have been constrained to a broad age range between I78 and I60 Ma spanning the Middle Jurassic, however, further work is encouraged to better define the age of the Warnie Volcanic Province.

\subsection{Structural Controls on the Emplacement of the Warnie Volcanic Province}

From the late Triassic to the early Jurassic, the Eromanga Basin was subject to an east-west compressional event named the Hunter-Bowen event (Mayromatidis, 2005; Kulikowski \& Amrouch, 2017), which uplifted the basin and inverted the major highs. Subsequently, the basin underwent post-compressional flexural relaxation with the resultant accommodation space infilled by the Middle to Late Jurassic succession discussed within this manuscript (LoweYoung, 1997; Mayromatidis, 2005). During this time, a strike-slip extensional regime is thought to have been present (Kulikowski, 2018). In this context, it is interesting to consider whether the stress regime of the Cooper Basin helped to control the location and morphology of igneous rocks within the WVP and, more broadly, the location of the WVP within central Australia.

\subsection{The Influence of Basement Structure on the Location of lgneous Rocks}

Within other basins, such as those in the North Atlantic, it has been noted how the location of igneous intrusions and volcanism is controlled by the basin structure, in particular the location of major faults (Schofield et al., 2015; McClean et al., 2017; Hardman et al., 2018a). To investigate whether basement structure and faulting had a direct control on volcanism erupted during the Jurassic, we have utilised the 3D seismic reflection datasets available.

We have already considered the Top Basement structure within the Winnie 3D survey and interpreted faulting of the Top Basement, in particular the $25 \mathrm{~km}$ long Central Nappamerri Fault. We superimposed the location of vents within the Winnie 3D survey on top of a TWT 
map of the Top Basement to see if there was any relationship between basement structure and the location of the vents (Fig. 9C). On a broad scale, two vents are located directly above the Central Nappamerri Fault (CNF) with the others situated adjacent to the mapped Top Basement Horizon (i.e. where it deepens to $>3600 \mathrm{~ms}$ and is no longer mappable). On a broad scale, the location of vents does appear to be related to the basement structure.

We also superimposed the location of the Madigan 3D volcanoes on top of the NGMA (2003) basement map (Fig. 25). Like the igneous rocks in the Winnie 3D survey, the two volcanoes imaged in the Madigan 3D survey sit atop the tip of the $25 \mathrm{~km}$ Challum Fault and atop a second, $\sim 5 \mathrm{~km}$ fault northwest of the main Challum Fault. This reinforces the idea that the location of igneous rocks was largely controlled by the basin structure.

\subsubsection{The Influence of Discontinuities and Faults within the Eromanga Succession on the Morphology of Igneous Rocks}

Here, we consider how basin structure controlled the morphology of igneous rocks within the Nappamerri Trough. Using the Winnie 3D survey, the length, width and elongate direction of the volcanoes, lava flows and intrusions was picked (Fig. 23). The high quality of the Winnie 3D survey facilitated confident mapping of the outline of individual volcanic events, however, the Gallus 2D and Snowball 3D surveys were not considered as the outline of individual volcanics could not be picked confidently. The data shows that igneous rocks in the area are roughly/typically twice as long as they are wide (Fig. 23). Furthermore, almost all the igneous rocks are elongated in a NW-SE direction, closely matching the strike of the faults within the Nappamerri Trough. It is clear that during eruption and emplacement of the igneous rocks, the basin structure exerted a strong control on the morphology of lava flows and igneous intrusions.

However, we have also considered fracturing and faulting within the Eromanga succession and its control on the morphology of lava flows and igneous intrusions in the Nappamerri Trough. In vertical seismic reflection sections, faulting of the Eromanga Basin stratigraphy is not clearly imaged within the Winnie 3D survey, largely due to the considerable noise within the section. However, spectral decomposition produced for the Top Volcanics horizon images a number of discontinuities (shown as black lines) within the colour blend (Fig. 24A). These discontinuities are not thought to be a product of the acquisition and processing of the seismic data, due to their non-linear nature and their coincidence with other geological features such 
as the igneous rocks and the CNF. When mapped, the features form a series of largely NESW trending lineaments (Fig. 24B). Although imaging of the discontinuities is best in the SW of the survey, where there are fewer igneous rocks, it is evident that many of the igneous rocks are aligned with these features suggesting they must have exerted some topographical or structural control when the igneous rocks were emplaced or erupted over the Nappamerri Trough (Fig. 24). As they do not resemble any sedimentary features such as valleys or fluvial systems, we interpret these features to be faulting or fracturing of the Eromanga succession above the Nappamerri Trough.

Determining the tectonic activity responsible for the faulting within the Nappamerri Trough and, hence, the location and morphology of igneous rocks within the WVP is difficult due to the complex structural and stress history of the Cooper Basin. Throughout the basin, a conjugate set of large NNE-SSW and field scale SE-NW striking dextral strike-slip faults developed under a SSE-NNW strike-slip stress regime (Kulikowski et al., 20I8). This is pertinent when applied to the central Nappamerri Trough, as Kulikowski et al. (2018) identified a series of vertical SE-NW structural lineaments with normal displacement or no displacement. Due to their vertical nature, it is thought that these faults developed as strike slip faults during successive periods of flexural relaxation or sag. The faulting identified within this study is also determined to consist of little offset with an orientation that matches that of the strike-slip faulting determined by Kulikowski et al., (2008) (Fig. 24A-D). We surmise that sag within the basin produced a series of faults and fractures within the basin that controlled the morphology of igneous rocks in the WVP.

\subsection{The Plumbing System of the WVP}

Due to the risks associated with drilling igneous rocks within the Warnie Volcanic Province, being able to identify the presence of them is especially important. Whilst this manuscript has dealt with surface vents, flows and shallowly emplaced igneous intrusions ( 100-200 ms below the paleo land surface, here believed to be Top Birkhead), we have only briefly discussed the plumbing system of the Warnie Volcanic Province and the lack of constraint on the presence of dykes and deeper sills

Within this study we have already noted that vents are observed to extend through the Cooper Basin succession, below the extrusive and intrusive igneous rocks identified in the Eromanga Basin succession above (e.g. Fig. 9). Vents are positioned directly above visible offset 
in the basement or adjacent basement highs (Fig. 9C). Furthermore, when viewed in a TWT cross section, the vents are all vertical, with no sills observed $>200$ ms below the palaeo-land surface (taken here to be Top Birkhead). This suggests that the magmatic plumbing system of the WVP is dominantly vertical throughout the Nappamerri Trough.

However, whilst the intrusions identified within the Winnie 3D survey are emplaced at shallow depths ( 100-200 ms in Fig. 8) below the palaeo-land surface, the intersection of an intrusion within the Permian succession of the Warnie East well $(410 \mathrm{~m}$ below the Birkhead Fm., Fig. 14) suggests that the plumbing system of the WVP is not well understood and may be subject to lateral transport of magma, in addition to the predominantly vertical vents observed in this manuscript. When detailing the magnetic data we discussed the importance of a $\sim 75 \times 40 \mathrm{~km}$ magnetic intensity high that runs from the Innamincka Ridge across the northern extent of the WVP in a NW-SE direction (Fig. 22B). Without good seismic imaging of the stratigraphy below the Permian Cooper Basin succession, it is difficult to confidently identify what this represents. Notably, it does not correspond to an increase in the concentration of extrusive volcanics, otherwise this would have been imaged in the Gallus 2D survey (Fig. I IA). This $75 \times 40 \mathrm{~km}$ magnetic anomaly could be an expression of an extensive network of igneous intrusions that are not imaged within the available data, however, a confident interpretation would require high quality 3D seismic reflection survey data covering the area north of the Winnie 3D survey.

\subsection{The Broader Record of Jurassic Volcanism in Eastern Australia}

We believe it is important to consider the WVP in the context of the broader record of Jurassic volcanic activity in eastern Australia. Coeval with the eruption of the WVP, the Eromanga Basin was undergoing post-compressional flexural relaxation with thermally controlled subsidence in the absence of significant fault control (Gallagher \& Lambeck, 1989 Mayromatidis, 2005). Subsidence has been attributed to subduction of the Pacific plate beneath southern and eastern Australia, during which time rifting also initiated between Australia and Antarctica (Griffiths, I97I; Johnstone et al., 1973).

Evidence for Jurassic volcanic activity is pervasive throughout the sedimentary basins of eastern Australia, manifested by volcanic arc-derived sediment within the Eromanga Basin (Boult et al., 1998), silicic tuffs in the Surat Basin (Wainman et al., 2015) and widespread volcanogenic zircons within the Eromanga Basin (Bryan et al., 1997). This volcaniclastic 
material is thought to be derived from an acid to intermediate volcanic arc positioned off the coast of Queensland during the Jurassic however, the remnants of this arc volcanism are yet to be identified (Patton, 1986, Boult et al., 1997). Jurassic alkali basalt has been intersected on the Marion Plateau ( $400 \mathrm{~km}$ east of Townsville in Queensland), although this may also be related to rifting in the region during the Jurassic (Isern et al., 2002).

1500 km south of the Marion Plateau, mafic and ultramafic breccia pipes and igneous intrusions are noted in the Eastern Highlands and Sydney Basin with K-Ar dating suggesting ages of between 193 and $163 \mathrm{Ma}$ (McDougall and Wellman, 1976). To the north west of the Syndey Basin, in New South Wales, lower Jurassic intrusions and volcanics of the Garawilla alkali basalts and alkaline Mittagong complexes are noted in the Gunnedah Basin (195- $177 \mathrm{Ma}$ ) (Sutherland, 1973, Gurba \& Weber, 200I). Further south of the Sydney and Gunnedah basins, Jurassic volcanics are scattered throughout Victoria and Tasmania (Veevers, 1984). These include voluminous tholeiitic intrusions in Tasmania (I65 m.y.) that are thought to have been buried under a thick pile of since eroded extrusive volcanics (Sutherland, 1973; McDougall \& Wellman, 1976).

$\sim 1000 \mathrm{~km}$ to the north-west, the Wisanger Basalt is a $\sim 170 \mathrm{Ma}, 20 \mathrm{~km}$ fragmented lava flow emplaced on top of Permian fluviatile sediments on Kangaraoo Island (McDougall \& Wellman, 1976). Geochemically, it is similar to the Tasmanian and Antarctic tholeiitic dolerite and basalts that are usually attributed the Ferrar Large Igneous Province and extension that latterly resulted in the separation of Australia and Antarctica (Compston et al., 1968; Milnes et al., 1982). Of note in South Australia, Jurassic kimberlites record the extension of Mesozoic kimberlites found along the margin of southern Gondwana, above the subducting Pacific plate (Tappert et al., 2009), differing petrologically from the predominantly basaltic volcanism found elsewhere in eastern Australia.

Plate reconstructions indicate that the Eromanga Basin was located at significant distances $(\sim 750 \mathrm{~km})$ from the oceanic trench of the subducting Pacific plate (Veevers, 1984) (Fig. 27). Importantly, alongside the WVP, the South Australian Kimberlites are the only other Jurassic volcanics documented in eastern Australia that occur away (>500 km) from a significant plate boundary (here we have ascribed the Wisanger Basalts to the zone of separation between Australia and Antarctica and, hence, a 'significant' plate boundary). We therefore believe the Warnie Volcanic Province to be an intraplate volcanic province and, as the origin of intraplate 
volcanism can often be contentious (Conrad et al., 20I I), it is important to consider the source of this volcanism and implications for the formation of intraplate volcanism.

\subsection{The Origin of the Warnie Volcanic Province}

The WVP was located far from active plate boundaries during the Jurassic (Fig. 27A). When considering the source of intraplate volcanism, several different mechanisms must be considered:

- The presence of a mantle plume

- Asthenospheric upwelling due to extension

- Local scale mantle convection

Mantle plumes are typically associated with the eruption of voluminous flood basalt provinces that often mark the earliest volcanic activity of major hot spots (Richard et al., 1989). Furthermore, mantle plumes cause dynamic uplift of the land's surface of up to several hundred kms followed by surface subsidence due to the withdrawal of mantle plume material and loading of the crust with the volcanic sequence (Nadin et al., 1997; Dam et al., 1998; Leng \& Zhong, 2010; Hartley et al., 20I I; Hardman et al., 2018b). No evidence of major surface uplift in the Cooper and Eromanga Basins is coeval with the emplacement and eruption of the WVP (Hall et al., 2015). Furthermore, subsidence and sag throughout the emplacement of the WVP is minor, with no large changes in sedimentary facies noted throughout the Jurassic lower non-marine Eromanga succession (Alexander \& Hibburt, 1996). No major crustal and/or lithospheric extension is evidenced by the lack of major Jurassic faults, during a time in which the basin underwent post-compressional flexural relaxation in a strike slip extensional regime (Lowe-Young, 1997; Mayromatidis, 2005; Kulikowski, 2018). Furthermore, the small spatial area covered by the Warnie Volcanic Province $\left(\sim 7500 \mathrm{~km}^{2}\right.$ within the Nappamerri Trough area) and, by extension, the volume of magma emplaced is too low to be related to a mantle plume source (Conrad et al., 20I I).

Low-effusive volcanism occurring within tectonic plates has been also attributed to several locally operating processes, such as minor upwelling plumes (Courtillot et al., 2003; Conrad et al., 201 I), downwelling drops (Elkins-Tanton et al., 2006) and sub-lithospheric (Ballmer et al., 2009) or edge-driven convection (Conrad et al., 2010). In the case of edgedriven convection, mantle flow can induce upwelling and volcanism through interaction with lithospheric or asthenospheric heterogeneities (Conrad et al., 201I; Davies \& Rawlinson, 
2014). In the Newer Volcanic Province in South Australia, $<5 \mathrm{kyr}$ volcanism forming as a product of edge driven convection is noted to consist of basaltic monogenetic volcanoes $<4$ $\mathrm{km}^{2}$ in size covering an area of $\sim 20,000 \mathrm{~km}^{2}$ (Demidjuk et al., 2007; Davies \& Rawlinson, 20 I4), bearing a striking similarity to the WVP (the volcanism is basaltic and individual volcanoes like Mount Gambier are of a similar scale $(\sim 1.5 \times 1.5 \mathrm{~km})$ to the volcanoes imaged in the Nappamerri Trough area). Although not much is known about the crustal structure below the eastern Nappamerri Trough, seismic reflection profiles have revealed that Devonian troughs to the east of the study area are associated with crustal thinning of $7-10 \mathrm{~km}$ (Mathur, 1983). Furthermore, on a continental scale, the Moho is observed to shallow to $\sim 20 \mathrm{~km}$ below the Cooper Basin (and more broadly, Central Australia) (Kennett et al., 20II). Therefore, there is observable lithospheric thinning below the basins in Central Australia that could have produced edge driven convection.

However, because Central Australia was relatively inactive during the Jurassic, we must consider driving mechanisms for asthenospheric flow beneath the continent during the eruption and emplacement of the WVP. As we have already detailed, the Pacific plate was subducting beneath eastern Australia during the Jurassic. In intraplate volcanic provinces adjacent to subduction zones (e.g. Western North America, China), there is a causal link between subduction and intraplate volcanism, in that subduction below the continental crust acts as a driving force for asthenospheric shear and, hence, the mantle upwelling that produces intraplate volcanism (Conrad et al., 20I I; Tang et al., 20I4; Zhou et al., 20I8). If the extension in the area during the Jurassic is not great enough to stimulate volcanism, then an alternative model may involve rapid asthenospheric shear produced by the subducting Pacific Plate, localised beneath SW Queensland due to edge driven convection.

We propose a model for the Warnie Volcanic Province based on our understanding of the lithospheric and geodynamic state of Central Australia in the Middle to Late Jurassic. We propose that asthenospheric shear above the subducting pacific plate stimulated mantle flow below Australia. Localisation of mantle flow occurred beneath southwest Queensland because of edge driven convection leading to emplacement of the Warnie Volcanic Province above the Nappamerri Trough. Despite our proposed model, we strongly believe that more work needs to be conducted on the area before it can be concluded what the source of the WVP is. In the Newer Volcanic Province of southeastern Australia, geochemistry, in particular major and trace element analysis, provided insights into why mantle melting occurred in the absence of extension or a mantle plume (Demidjuk et al., 2007). As such, we would strongly 
recommend further studies to be conducted on the geochemical signature of the basalts of the WVP.

Due to its low volume and small areal extent, we do not believe that the WVP was the source of the volcanically derived sediment that was distributed throughout much of Australia during the Mesozoic (Boult et al., 1998; MacDonald et al., 20I3; Barham et al., 2016). However, our findings raise the possibility that other, yet unidentified, intra-basinal volcanic sources may contribute to Mesozoic volcanogenic sedimentation in eastern Australia.

Finally, it must be considered why the WVP has not been documented until now despite the presence of volcanic rocks being known for over three decades. By our estimates, only $0.13 \%$ of the wells drilled in the Cooper Basin between 1959 and 2015 drilled the WVP (based on Hall et al., 2016's estimate of the number of wells), with 35 years of exploration since the first well that drilled the volcanics. This is despite the WVP occupying $\sim 6 \%$ of the geographic extent of the Cooper Basin. Largely, this is due to the lack of data and attention given to the Nappamerri Trough region until recently. Acquisition of the high-quality Winnie 3D seismic reflection survey facilitated confident delineation of the WVP. This study also underlines the importance for collaboration between industry and academia. Whilst volcanics have been described within industry reports and imaged within data acquired, they have been overlooked within the literature. The obscurity of the WVP in an area of such intense exploration points to the probability of other undiscovered volcanic provinces globally. It is therefore an important analogue in the search for undiscovered intraplate volcanism that may inform our understanding of the mantle processes occurring beneath continental interiors.

\section{Conclusions}

We have integrated seismic, well, gravity and magnetic data and clarified the extent and character of igneous rocks emplaced above the Nappamerri Trough of the Cooper Basin within Eromanga Basin stratigraphy. Monogenetic volanoes, igneous intrusions and compound lava flows extending over $\sim 7500 \mathrm{~km}^{2}$ are proposed to have been active between $\sim 180-160$ Ma forming part of the proposed 'Warnie Volcanic Province.' Regionally, the distribution of igneous rocks is controlled by basement structure. On a continental scale, we interpret the Warnie Volcanic Province to be a product of intraplate convective upwelling above the subducting Pacific slab. 


\section{I0. Acknowledgements}

955 We wish to thank Santos Ltd. for providing us with the Snowball 3D seismic survey. In particular we 956 wish to thank Jenni Clifford and Lance Holmes who provided helpful feedback and 2D seismic lines 957 covering the Lambda I, Orientos 2 and Warnie East I wells. We also wish to thank Beach Energy, in 958 particular Rob Menpes, for the helpful discussions and feedback on the manuscript in addition 959 to helping us with the analysis of the magnetic data. The work contained in this paper contains 960 work conducted during a PhD study undertaken as part of the Natural Environment Research Council 961 (NERC) Centre for Doctoral Training (CDT) in Oil \& Gas [grant number NEM00578X/I] and is fully funded by NERC whose support is gratefully acknowledged

963

964

965

966 
968

969

970

971

972

973

974

975

976

977

978

979

980

981

982

983

984

985

986

987

988

989

990

991

992

993

994

995

996

997

998

999

\section{References}

Alexander, E.M. and Sansome, A., 1996, Lithostratigraphy and Environments of Deposition, in Alexander, E.M. and Hibburt, J., (Eds), Petroleum Geology of South Australia, Volume 2: Eromanga Basin, p 49 - 86.

Allen P., 1998. Kappa I Well Completion Report. Compiled for Santos Limited.

Archer, S.G., Bergman, S.C., Iliffe, J., Murphy, C.M. and Thornton, M., 2005. Palaeogene igneous rocks reveal new insights into the geodynamic evolution and petroleum potential of the Rockall Trough, NE Atlantic Margin. Basin Research, I7(I), pp. I7I-20I.

Bacchin, M., Milligan, P. R., Wynne, P., and Tracey, R., 2008. Gravity Anomaly Map of the Australian Region (third edition, scale I:I5 000 000, Geoscience Australia, Canberra.Baker, J.C.,

Bai, G.P., Hamilton, P.J., Golding, S.D. and Keene, J.B., 1995. Continental-scale magmatic carbon dioxide seepage recorded by dawsonite in the Bowen-Gunnedah-Sydney Basin system, eastern Australia. Journal of Sedimentary research, 65(3).

Baksi, Ajoy K. "Critical evaluation of the age of the Deccan Traps, India: Implications for flood-basalt volcanism and faunal extinctions." Geology 15.2 (1987): I47-I50.

Barham, M., Kirkland, C.L., Reynolds, S., O’Leary, M.J., Evans, N.J., Allen, H., Haines, P.W., Hocking, R.M., McDonald, B.J., Belousova, E. and Goodall, J., 20I6. The answers are blowin'in the wind: Ultradistal ashfall zircons, indicators of Cretaceous super-eruptions in eastern Gondwana. Geology, 44(8), Pp.643-646.

Beeson, Marvin H., Terry L. Tolan, and James Lee Anderson. "The Columbia River Basalt Group in western Oregon; geologic structures and other factors that controlled flow emplacement patterns." Geological Society of America Special Papers 239 (1989): 223-246.

Bell \& Butcher, 2002. On the emplacement of sill complexes: evidence from the Faroe-Shetland Basin. Geological Society, London, Special Publications(2002), 197(I):307

Boothby, P.G., 1986. Warnie East I Well Completion Report. Compiled for Delhi Petroleum Pty Ltd.

Breed, W.J., 1964. Morphology and lineation of cinder cones in the San Francisco Volcanic Field. Mus. North. Ariz. Bull, 40, pp.65-7I.

Bryan, S.E., Constantine, A.E., Stephens, C.J., Ewart, A., Schön, R.W. and Parianos, J., 1997. Early Cretaceous volcano-sedimentary successions along the eastern Australian continental margin: Implications for the break-up of eastern Gondwana. Earth and Planetary Science Letters, I53(I), pp.85102 
1000

1001

1002

1003

1004

1005

1006

1007

1008

1009

1010

1011

1012

1013

1014

1015

1016

1017

1018

1019

1020

1021

1022

1023

1024

1025

1026

1027

1028

1029

1030

1031

Bucknill, M., 1990. Orientos 2 Well Completion Report. Compiled for Delhi Petroleum Pty Limited. Burger, D. and Senior, B.R., 1979. A revision of the sedimentary and palynological history of the northeastern Eromanga Basin, Queensland. Journal of the Geological Society of Australia, 26(3-4), Pp.I2I133.

Cas, R.A.F., van Otterloo, J., Blaikie, T.N. and van den Hove, J., 20I7. The dynamics of a very large intra-plate continental basaltic volcanic province, the Newer Volcanics Province, SE Australia, and implications for other provinces. Geological Society, London, Special Publications, 446(I), pp. I23-I72

Christie, P., Gollifer, I. and Cowper, D., 2006. Borehole seismic studies of a volcanic succession from the Lopra-I/IA borehole in the Faroe Islands, northern North Atlantic. Geological Survey of Denmark and Greenland Bulletin, 9, pp.23-40.

Compston, W., McDougall, I. and Heier, K.S., 1968. Geochemical comparison of the mesozoic basaltic rocks of Antarctica, South Africa, South America and Tasmania. Geochimica et Cosmochimica Acta, 32(2), pp.129-149.

Conrad, C.P., Bianco, T.A., Smith, E.I. and Wessel, P., 20I I, Patterns of intraplate volcanism controlled by asthenospheric shear, Nature Geoscience, v. 4, p. 317-32I.

Davies, D.R. and Rawlinson, N., 2014, On the origin of recent intraplate volcanism in Australia, Geology, v. 42, pp. I03I-1034.

Demidjuk, Z., Turner, S., Sandiford, M., George, R., Foden, J. and Etheridge, M., 2007, U-series isotope and geodynamic constraints on mantle melting processes beneath the Newer Volcanic Province in South Australia, Earth and Planetary Science Letters, v. 26I, p. 5I7-533.

Draper, J.J. ed., 2002. Geology of the Cooper and Eromanga Basins, Queensland. Department of Natural Resources and Mines

Duddy, I.R., 2003. Mesozoic: a time of change in tectonic regime. Geology of Victoria, Pp.239-286.

Ebinghaus, A., Hartley, A.J., Jolley, D.W., Hole, M. and Millett, J., 20I4. Lava-Sediment Interaction and Drainage-System Development In A Large Igneous Province: Columbia River Flood Basalt Province, Washington State, US ALAVA-DRAINAGE INTERACTION, COLUMBIA RIVER FLOOD BASALT PROVINCE. Journal of Sedimentary Research, 84(I I), Pp. I04 I-I 063.

Gallagher, K. and Lambeck, K.U.R.T., 1989, Subsidence, sedimentation and sea-level changes in the Eromanga Basin, Australia, Basin Research, v. 2, p. II5-131.

Gallagher, K., 1990. Permian to Cretaceous subsidence history along the Eromanga-Brisbane geoscience transect. The Eromanga-Brisbane Geosciences Transect: A Guide to Basin Development across Phanerozoic Australia in Southern Queensland: Bureau of Mineral Resources Bulletin, 232, Pp. I33-I5I. 
1032

1033

1034

1035

1036

1037

1038

1039

1040

1041

1042

1043

1044

1045

1046

1047

1048

1049

1050

1051

1052

1053

1054

1055

1056

1057

1058

1059

1060

1061

1062

1063

Gatehouse, C.G., 1972, Formations of the Gidgealpa Group in the Cooper Basin., Australasian Oil and Gas Review, I8(12), 10-15

Gebhardt, A.C., De Batist, M., Niessen, F., Anselmetti, F.S., Ariztegui, D., Haberzettl, T., Kopsch, C., Ohlendorf, C. and Zolitschka, B., 20I I. Deciphering lake and maar geometries from seismic refraction and reflection surveys in Laguna Potrok Aike (southern Patagonia, Argentina). Journal of Volcanology and Geothermal Research, 20 I(I-4), pp.357-363.

Glass, L.M. and Phillips, D., 2006, The Kalkarindji continental flood basalt province: A new Cambrian large igneous province in Australia with possible links to faunal extinctions, Geology, v. 34, p. 46I-464.

Goldstein, B., Menpes, S., Hill, A., Wickham, A., Alexander, E., Jarosz, M., Pepicelli, D., Malavazos, M., Staritski, K., Taliangis, P., Coda, J., Hill, D. \& Webb, M. 20I2. Roadmap for Unconventional Gas Projects in South Australia. South Australia Department for Manufacturing, Innovation, Trade, Resources and Energy, Energy Resources Division, http://www.statedevelopment.sa.gov.au/resources/unconventional-gas-projects

Gravestock, D.I., Hibburt, J. and Drexel, J.F. eds., 1998. Petroleum Geology of South Australia: Cooper Basin. Petroleum Group, Primary Industries and Resources SA.

Greenstreet, C. 2015. From play to production: the Cooper unconventional story -20 years in the making. APPEA 2015 extended abstract.

Griffiths, J.R., 1975. New Zealand and the Southwest Pacific margin of Gondwanaland. In: K.S.W. Campbell (Editor), Gondwana Geology. A.N.U. Press, Canberra, pp. 619- 637.

Grove, C., 20I4. Direct and indirect effects of flood basalt volcanism on reservoir quality sandstone (Doctoral dissertation, Durham University).

Gurba, L.W. and Weber, C.R., 200I, Effects of igneous intrusions on coalbed methane potential, Gunnedah Basin, Australia, International Journal of Coal Geology, v. 46, p. I I3-I3I.

Hall, L.S., Hill, A.J., Troup, A., Korsch, R.J., Radke, B.M., Nicoll, R.S., Palu, T., Wang, L. and Stacey, A., 2016, Cooper Basin Architecture and Lithofacies, Geoscience Australia.

Hall, L.S, Palu, T.J., Murray, A.P., Boreham, C.J., Edwards, D.S., Hill, A.J., Troup, A., 2018.

Hydrocarbon Prospectivity of the Cooper Basin, Australia. AAPG Bulletin.

Hamilton, D.S., Holtz, M.H., Ryles, P., Lonergan, T. and Hillyer, M., 1998. Approaches to identifying reservoir heterogeneity and reserve growth opportunities in a continental-scale bed-load fluvial system: Hutton Sandstone, Jackson field, Australia. AAPG bulletin, 82(12), pp.2192-2219.

Heine, C. and Müller, R.D., 2005. Late Jurassic rifting along the Australian North West Shelf: margin geometry and spreading ridge configuration. Australian Journal of Earth Sciences, 52(I), pp.27-39. 
Hillis, R.R., Morton, J.G.G., Warner, D.S. and Penney, R.K., 200I. Deep basin gas: A new exploration paradigm in the Nappamerri Trough, Cooper Basin, South Australia. The APPEA Journal, 4I(I), pp. $185-200$.

Holford, S.P., Schofield, N., Jackson, C.L., Magee, C., Green, P.F. and Duddy, I.R., 20I3. Impacts of igneous intrusions on source reservoir potential in prospective sedimentary basins along the western Australian continental margin.

Holt, S.J., Holford, S.P. and Foden, J., 2013. New insights into the magmatic plumbing system of the South Australian Quaternary Basalt province from 3D seismic and geochemical data. Australian Journal of Earth Sciences, 60(8), pp.797-8I7.

Homberg, C., Hu, J.C., Angelier, J., Bergerat, F. and Lacombe, O., 1997. Characterization of stress perturbations near major fault zones: insights from 2-D distinct-element numerical modelling and field studies (Jura mountains). Journal of Structural Geology, 19(5), pp.703-7I8.

Hulme, G., 1974. The interpretation of lava flow morphology. Geophysical Journal International, 39(2), PP.36I-383.

Isern, A.R., Anselmetti, F.S. and Blum, P., 2002. Constraining Miocene sea level change from carbonate platform evolution, Marion Plateau, northeast Australia, Sites I192-I 199. In Proceedings of the Ocean Drilling Program. Initial Reports (Vol. 194, p. 88)

Jell, P.A. ed., 2013. Geology of Queensland. Geological Survey of Queensland.

Jerram, D.A. and Widdowson, M., 2005. The anatomy of Continental Flood Basalt Provinces: geological constraints on the processes and products of flood volcanism. Lithos, 79(3), pp.385-405.Beeson, 1989

Johnstone, M.H., Lowry, D.C. and Quilty, P.G., 1973. The geology of South-western Australia - a review. J. Proc. R. Sot. West. Aus., 56: 5-I5.

Kelley, S. (2002) K-Ar and Ar-Ar Dating, in noble gases in geochemistry and cosmochemistry. In: Reviews in Mineralogy and Geochemistry, Vol. 47 (Ed. by D. Porcelli, C.J. Ballentine \& R. Wieler), PP. 785-818, Mineral Society America, Washington, DC.

Kennett, B., Salmon, M., Saygin, E. and AusMoho Working Group., AusMoho: the variation of Moho depth in Australia, Geophysical Jounral International, I87, 946-958, 201 I, doi:I0.1 II I/j. I365246X.2011.05194.x

Kereszturi, G. and Németh, K., 2012. Monogenetic basaltic volcanoes: genetic classification, growth, geomorphology and degradation. In Updates in Volcanology-New Advances in Understanding Volcanic Systems. InTech

Kermani, M.B. and Morshed, A., 2003. Carbon dioxide corrosion in oil and gas production-a compendium. Corrosion, 59(8), pp.659-683. 
1097

1098

1099

1100

1101

1102

1103

1104

1105

1106

1107

1108

1109

1110

1111

1112

1113

1114

1115

1116

1117

1118

1119

1120

1121

1122

1123

1124

1125

1126

1127

Khair, H.A., Cooke, D. and Hand, M., 20I3. The effect of present day in situ stresses and paleostresses on locating sweet spots in unconventional reservoirs, a case study from Moomba-Big Lake fields, Cooper Basin, South Australia. Journal of Petroleum Exploration and Production Technology, 3(4), Pp.207-22I.

Khair, H.A., Cooke, D. and Hand, M., 2015. Seismic mapping and geomechanical analyses of faults within deep hot granites, a workflow for enhanced geothermal system projects. Geothermics, 53, Pp.46-56.

Khair, H.A., Cooke, D. and Hand, M., 2015. Paleo stress contribution to fault and natural fracture distribution in the Cooper Basin. Journal of Structural Geology, 79, pp.3I-4I.

Kulikowski, D., Amrouch, K., Cooke, D. and Gray, M.E., 2018, Basement structural architecture and hydrocarbon conduit potential of polygonal faults in the Cooper-Eromanga Basin,

Australia, Geophysical Prospecting, v. 66, p. 366-396.

Lanzilli, E., 1999. The Birkhead Formation: reservoir characterisation of the Gidgealpa south dome and sequence stratigraphy of the Eromanga Basin, Australia (Doctoral dissertation, University of South Australia).

Leaman, D.E., 1975. Form, mechanism, and control of dolerite intrusions near Hobart, Tasmania. J. Geol. Sot. Aust., 22: 175-186.

Macdonald, G.A., 1972. Volcanoes, 510 pp.

MacDonald, J.D., Holford, S.P., Green, P.F., Duddy, I.R., King, R.C. and Backé, G., 20I3. Detrital zircon data reveal the origin of Australia's largest delta system. Journal of the Geological Society, I 70(I), pp.36.

Magee, C., Jackson, C.L. and Schofield, N., 20I4. Diachronous sub-volcanic intrusion along deep-water margins: Insights from the Irish Rockall Basin. Basin Research, 26(I), Pp.85-I05.

Magee, C., Muirhead, J.D., Karvelas, A., Holford, S.P., Jackson, C.A., Bastow, I.D., Schofield, N., Stevenson, C.T., McLean, C., McCarthy, W. and Shtukert, O., 2016. Lateral magma flow in mafic sill complexes. Geosphere, I2(3), pp.809-84I.

Mark, N.J., Schofield, N., Pugliese, S., Watson, D., Holford, S., Muirhead, D., Brown, R. and Healy, D., 2017. Igneous intrusions in the Faroe Shetland basin and their implications for hydrocarbon exploration; new insights from well and seismic data. Marine and Petroleum Geology.

Mathur, S.P., 1983, Deep crustal reflection results from the central Eromanga Basin,

Australia, Tectonophysics, v. 100, pp. 163-173. 
MCDOUGALL, I. \& WELLMAN, P. 1976. Potassium argon ages for some Australian Mesozoic igneous rocks. Journal of the Geological Society of Australia, 23, I-9.

McLean, C.E., Schofield, N., Brown, D.J., Jolley, D.W. and Reid, A., 2017. 3D seismic imaging of the shallow plumbing system beneath the Ben Nevis Monogenetic Volcanic Field: Faroe-Shetland Basin. Journal of the Geological Society, I 74(3), pp.468-485

Meeuws, F.J., Holford, S.P., Foden, J.D. and Schofield, N., 2016. Distribution, chronology and causes of Cretaceous-Cenozoic magmatism along the magma-poor rifted southern Australian margin: Links between mantle melting and basin formation. Marine and Petroleum Geology, 73, pp.27I-298.

Meixner, T.J., Gunn, P.J., Boucher, R.K., Yeates, T.N., Richardson, L.M. and Frears, R.A., 2000. The nature of the basement to the Cooper Basin region, South Australia. Exploration Geophysics, $3 /(2)$, Pp.24-32.

Menpes, S., Hill, A.J. \& Pepicelli, D. 2013. Characteristics of the Gidgealpa Group Composite Resource Play in the Cooper Basin, South Australia. Unconventional Resources Technology Conference, Denver, 2013.

Millett, J.M., Hole, M.J., Jolley, D.W., Schofield, N. and Campbell, E., 2016. Frontier exploration and the North Atlantic Igneous Province: new insights from a $2.6 \mathrm{~km}$ offshore volcanic sequence in the NE Faroe-Shetland Basin. Journal of the Geological Society, I73(2), pp.320-336.

Millett, J.M., Wilkins, A.D., Campbell, E., Hole, M.J., Taylor, R.A., Healy, D., Jerram, D.A., Jolley, D.W., Planke, S., Archer, S.G. and Blischke, A., 2016. The geology of offshore drilling through basalt sequences: Understanding operational complications to improve efficiency. Marine and Petroleum Geology, 77, pp.II77-I 192.

Milnes, A.R., Cooper, B.J. and Cooper, J.A., 1982. The Jurassic Wisanger Basalt of Kangaroo Island, South Australia. Transactions of the Royal Society of South Australia, 106, Pp. I-I3.

Murray, C.G., 1994. Basement cores from the Tasman fold belt system beneath the Great Artesian Basin in Queensland. Department of Minerals and Energy, Queensland.

Nadin, P.A., Kusznir, N.J. and Cheadle, M.J., 1997, Early Tertiary plume uplift of the North Sea and Faeroe-Shetland basins, Earth and Planetary Science Letters, v. I48, p. I09-I 27.

Nelson, C.E., Jerram, D.A. and Hobbs, R.W., 2009, Flood basalt facies from borehole data: implications for prospectivity and volcanology in volcanic rifted margins, Petroleum Geoscience, v. I5, p. 3|3-324.

Németh, K., 2010. Monogenetic volcanic fields: Origin, sedimentary record, and relationship with polygenetic volcanism. What is a Volcano?, 470, p.43. 
Németh, K. and Kereszturi, G., 2015. Monogenetic volcanism: personal views and discussion. International Journal of Earth Sciences, 104(8), pp.2I3I-2I 46.

Pitkin, M.C., Wadham, T.H., McGowen, J.M. and Thom, W.W., 2012, January. Taking the first steps: Stimulating the Nappamerri Trough resource play. In SPE Asia Pacific Oil and Gas Conference and Exhibition. Society of Petroleum Engineers.

Planke, S., Symonds, P.A., Alvestad, E. and Skogseid, J., 2000. Seismic volcanostratigraphy of largevolume basaltic extrusive complexes on rifted margins. Journal of Geophysical Research: Solid Earth, 105(B8), pp.19335-1935I.

Pokalai, K., Fei, Y., Ahmad, M., Haghighi, M. and Gonzalez, M., 2015. Design and optimisation of multi-stage hydraulic fracturing in a horizontal well in a shale gas reservoir in the Cooper Basin, South Australia. The APPEA Journal, 55(I), PP.I-I4.

Rateau, R., Schofield, N. and Smith, M., 2013. The potential role of igneous intrusions on hydrocarbon migration, West of Shetland. Petroleum Geoscience, 19(3), pp.259-272.

Reid, A.J., Korsch, R.J., Hou, B. and Black, L.P., 2009. Sources of sediment in the Eocene Garford paleovalley, South Australia, from detrital-zircon geochronology. Australian Journal of Earth Sciences, 56(SI), Pp.SI25-SI37.

Renaut, R.W., Jones, B., Tiercelin, J.J. and Tarits, C., 2002. Sublacustrine precipitation of hydrothermal silica in rift lakes: evidence from Lake Baringo, central Kenya Rift Valley. Sedimentary Geology, I 48(I-2), pp.235-257.

Reynolds, S.D., Mildren, S.D., Hillis, R.R., Meyer, J.J. and Flottmann, T., 2005, Maximum horizontal stress orientations in the Cooper Basin, Australia: implications for plate-scale tectonics and local stress sources, Geophysical Journal International, v. 160, p. 331-343.

Reynolds, P., Holford, S., Schofield, N. and Ross, A., 20I7. 3-D Seismic Imaging of Ancient Submarine Lava Flows: An Example From the Southern Australian Margin. Geochemistry, Geophysics, Geosystems.

Reynolds, P., Holford, S., Schofield, N. and Ross, A., 2017. The shallow depth emplacement of mafic intrusions on a magma-poor rifted margin: An example from the Bight Basin, Southern Australia. Marine and Petroleum Geology, 88, pp.605-616

Richards, M.A., Duncan, R.A. and Courtillot, V.E., 1989. Flood basalts and hot-spot tracks: plume heads and tails. Science, 246(4926), pp. $103-107$. 
Rider, M. and Kennedy, M., 20II. The Geological Interpretation of Well Logs.

"SA Department for Manufacturing, Innovation, Trade, Resources and Energy" (2003) National Geoscience Mapping Accord (NGMA) Cooper Eromanga Basins Project - Cooper Formation Depths. Bioregional Assessment Source Dataset. Viewed 27 November 2017, http://data.bioregionalassessments.gov.au/dataset/7d00f7c5-0ee3-407d-ac07-5c884c0c4b70. Schofield, N. and Jolley, D.W., 2013. Development of intra-basaltic lava-field drainage systems within the Faroe-Shetland Basin. Petroleum Geoscience, 19(3), pp.273-288.

Schofield, N., Holford, S., Millett, J., Brown, D., Jolley, D., Passey, S.R., Muirhead, D., Grove, C., Magee, C., Murray, J. and Hole, M., 2017. Regional magma plumbing and emplacement mechanisms of the Faroe-Shetland Sill Complex: implications for magma transport and petroleum systems within sedimentary basins. Basin Research, 29(I), pp.4I-63.

Schofield, N., Holford, S., Millett, J., Brown, D., Jolley, D., Passey, S.R., Muirhead, D., Grove, C., Magee, C., Murray, J. and Hole, M., 2017. Regional magma plumbing and emplacement mechanisms of the Faroe-Shetland Sill Complex: implications for magma transport and petroleum systems within sedimentary basins. Basin Research, 29(I), pp.4I-63.

Schofield, N., Jolley, D., Holford, S., Archer, S., Watson, D., Hartley, A., Howell, J., Muirhead, D., Underhill, J. and Green, P., 2018, January. Challenges of future exploration within the UK Rockall Basin. In Geological Society, London, Petroleum Geology Conference series (Vol. 8, No. I, pp. 2I I-229). Geological Society of London.

Scott, M.P., Stephens, T., Durant, R., McGowen, J., Thom, W. and Woodroof, R., 20I3, November. Investigating hydraulic fracturing in tight gas sand and shale gas reservoirs in the Cooper Basin. In SPE Unconventional Resources Conference and Exhibition-Asia Pacific. Society of Petroleum Engineers.

Segawa, J. and Oshima, S., 1975. Buried Mesozoic volcanic-plutonic fronts of the north-western Pacific island arcs and their tectonic implications. Nature, 256(55I2), p.I5.

Short, D.A., 1984. Lambda No.I Well Completion Report. Compiled for Delhi Petroleum Pty. Ltd. Song, B., Economides, M.J. and Ehlig-Economides, C.A., 20I I, January. Design of multiple transverse fracture horizontal wells in shale gas reservoirs. In SPE Hydraulic Fracturing Technology Conference. Society of Petroleum Engineers.

Stewart, A.K., Massey, M., Padgett, P.L., Rimmer, S.M. and Hower, J.C., 2005. Influence of a basic intrusion on the vitrinite reflectance and chemistry of the Springfield (No. 5) coal, Harrisburg, Illinois. International Journal of Coal Geology, 63(I-2), pp.58-67. 
1221

1222

1223

1224

1225

1226

1227

1228

1229

1230

1231

1232

1233

1234

1235

1236

1237

1238

1239

1240

1241

1242

1243

1244

1245

1246

1247

1248

1249

1250

1251

Stewart, A.J., Raymond, O.L., Totterdell, J.M., Zhang, W. \& Gallagher, R. 2013. Australian Geological Provinces, 2013.01 edition. scale 1:2 500 000. Geoscience Australia, Canberra, http://www.ga.gov.au/metadata-gateway/metadata/record/83860

Sutherland, F.L., 1978. Mesozoic-Cainozoic volcanism of Australia. Tectonophysics, 48(3-4), pp.4I3427.

Tang, Y., Obayashi, M., Niu, F., Grand, S.P., Chen, Y.J., Kawakatsu, H., Tanaka, S., Ning, J. and Ni, J.F., 2014. Changbaishan volcanism in northeast China linked to subduction-induced mantle upwelling. Nature Geoscience, 7(6), pp.470-475

Tappert, R., Foden, J., Stachel, T., Muehlenbachs, K., Tappert, M. and Wills, K., 2009. Deep mantle diamonds from South Australia: A record of Pacific subduction at the Gondwanan margin. Geology, 37(I), pp.43-46.

Tarling, D.H., 1966. The magnetic intensity and susceptibility distribution in some Cenozoic and Jurassic basalts. Geophysical Journal International, I I (4), pp.423-432.

Tracey R, Bacchin M, \& Wynne P., 2008, In preparation. AAGD07: A new absolute gravity datum for Australian gravity and new standards for the Australian National Gravity Database.

Exploration Geophysics.

Trude, J., Cartwright, J., Davies, R.J. and Smallwood, J., 2003, New technique for dating igneous sills, Geology, v. 3I, p. 8I3-8I6.

Tucker, R.T., Roberts, E.M., Henderson, R.A. and Kemp, A.I., 2016, Large igneous province or longlived magmatic arc along the eastern margin of Australia during the Cretaceous? Insights from the sedimentary record, Geological Society of America Bulletin, v. I28, p. I46 I-I 480.

Veevers, J.J. and Conaghan, P.J., 1984, Phanerozoic earth history of Australia, Oxford University Press, USA.

Wainman, C.C., Mccabe, P.J., Crowley, J.L. and Nicoll, R.S., 20I5, U-Pb zircon age of the Walloon Coal Measures in the Surat Basin, southeast Queensland: implications for paleogeography and basin subsidence, Australian Journal of Earth Sciences, v. 62, p. 807-816.

Wall, Mostyn, Joe Cartwright, Richard Davies, and Andrew McGrandle. "3D seismic imaging of a Tertiary Dyke Swarm in the Southern North Sea, UK." Basin Research 22, no. 2 (2010): 18I-194

Watson, D., Schofield, N., Jolley, D., Archer, S., Finlay, A.J., Mark, N., Hardman, J. and Watton, T., 2017. Stratigraphic overview of Palaeogene tuffs in the Faroe-Shetland Basin, NE Atlantic Margin. Journal of the Geological Society, I74(4), pp.627-645. 
1252 Watts, K.J., 1987, The Hutton Sandstone-Birkhead Formation Transition, ATP 269P(I), The APEA 1253 Journal, Volume 27 Number I, p 215 - 228.

1254 Wiltshire, M.J., 1989. Mesozoic stratigraphy and palaeogeography, eastern Australia Journal?

1255 Wood, C.A., 1980. Morphometric evolution of cinder cones. Journal of Volcanology and Geothermal 1256 Research, 7(3-4), pp.387-4I3.

1257 Yew, C.C. and Mills, A.A., 1989. The occurrence and search for Permian oil in the Cooper Basin, 1258 Australia. Journal?

1259 Zhou, Q., Liu, L. and Hu, J., 2018, Western US volcanism due to intruding oceanic mantle driven by 1260 ancient Farallon slabs, Nature Geoscience, v. I I, p. 70. 


\section{I2. Figures}
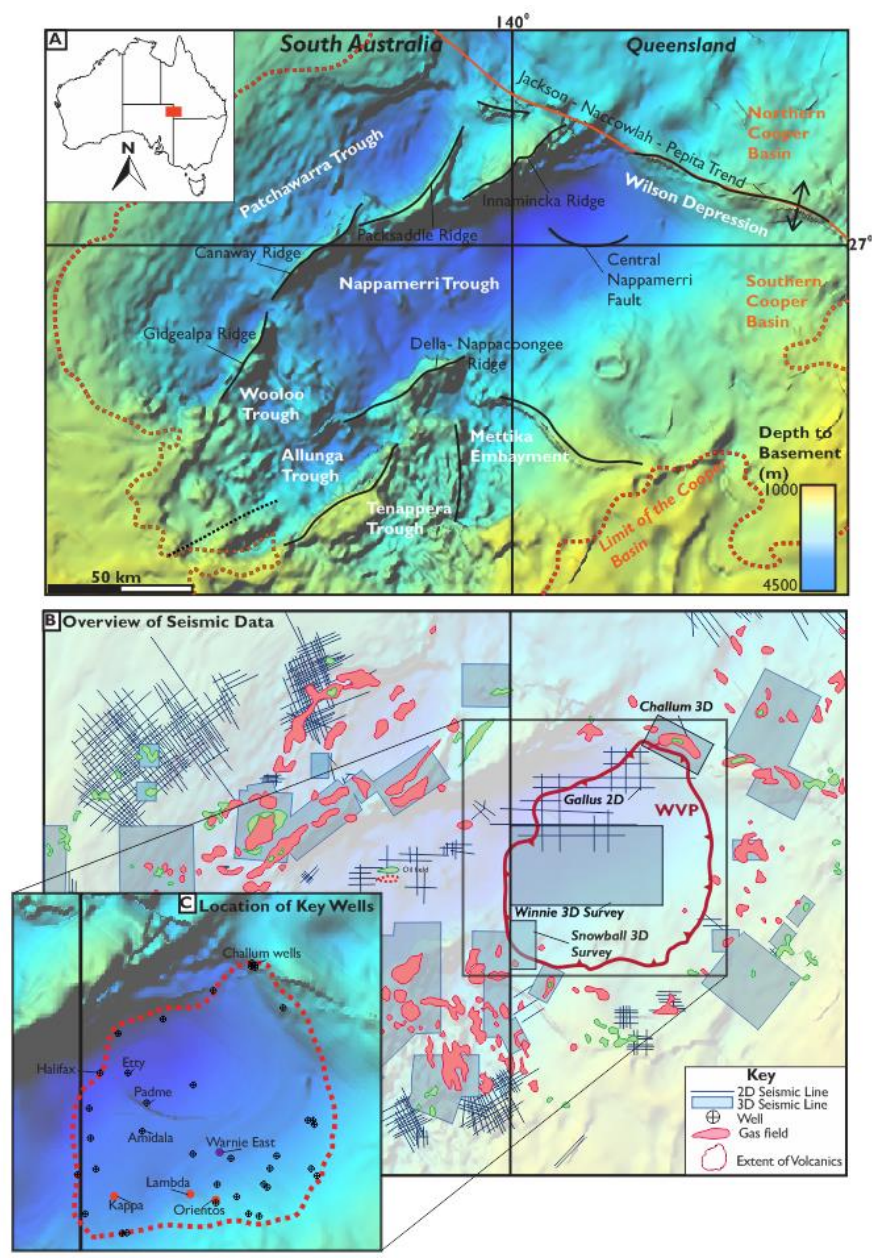

Figure I. Location map of the location of the Warne Volcanic Province and the data available. A Top basement map adapted from the NGMA (2003). Key structures of the southern Cooper Basin highlighted. B Location map highlighting the location of the Warne Volcanic Province within the Cooper Basin. Top basement map superimposed with the location of 3D and 2D seismic surveys utilised in this study and the location of key exploration wells. 


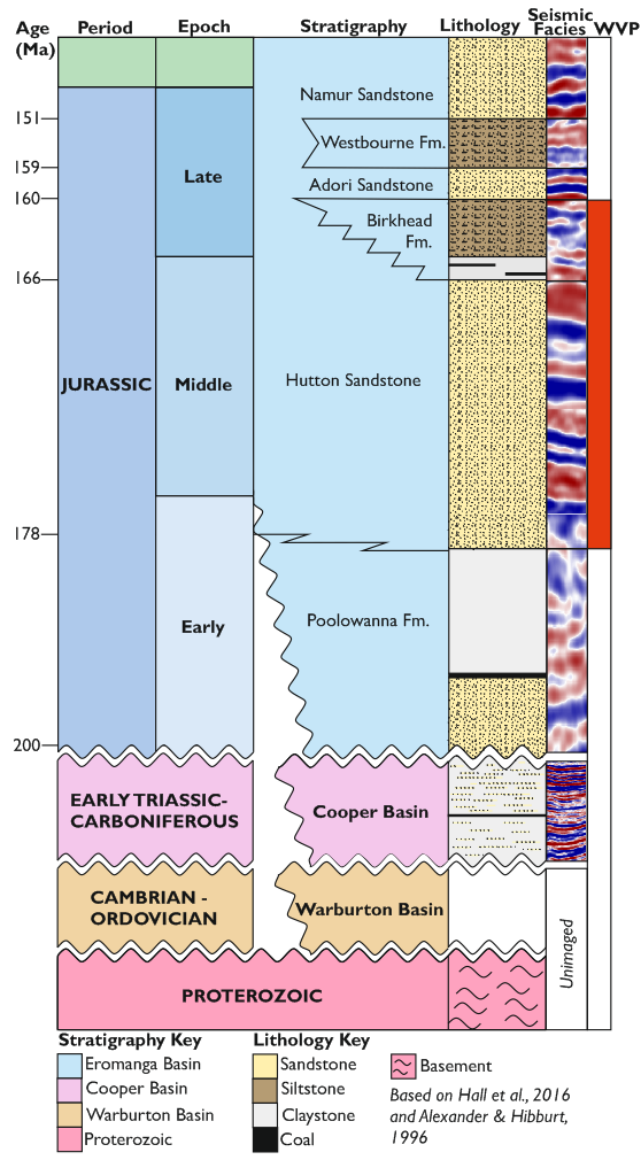

1271

1272 Figure 2. Stratigraphic column for the stratigraphy discussed within the paper, based on the work 1273 of Alexander \& Hibburt (1996), Hall et al. (2016) \& Reid et al. (2009). Seismic facies for each section 1274 is taken from the Winnie 3D survey of the eastern Nappamerri Trough. Rough stratigraphic location 1275 of the WVP highlighted. 


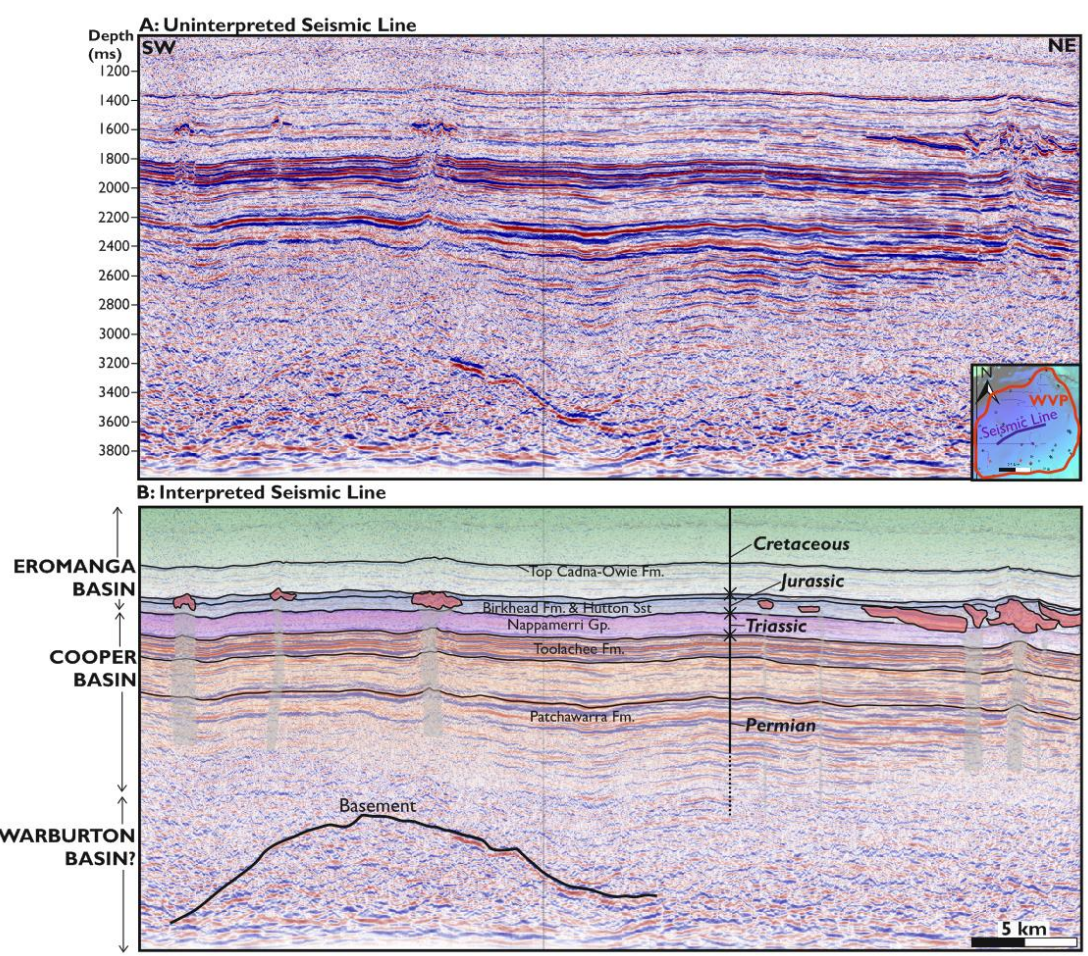

1278 Figure 3. Seismic line from the Winnie 3D survey of the Nappamerri Trough highlighting the broad 1279 stratigraphy of the study area. A Uninterpreted line. B Interpreted line. Note the stacked nature of 1280 the Eromanga, Cooper and Warburton Basins and the stratigraphic location of the Warne Volcanic Province. 

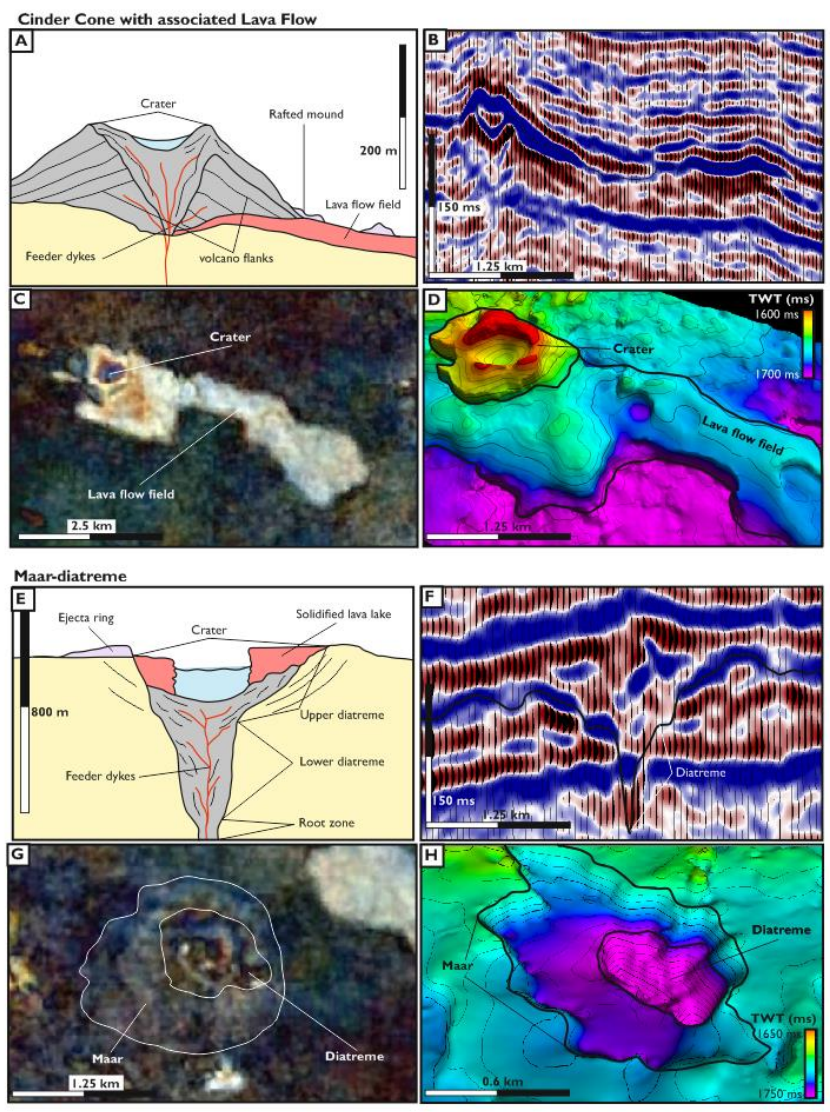

1284 Figure 4. Examples of different monogenetic vents. A Cross section through a cinder cone, adapted 1285 from Nemeth \& Kereszturi (2015). B Seismic line across a cinder cone and lava flow, taken from the 1286 Winnie 3D survey, highlighting the general morphology, seismic response. Note the characteristic eye shape within the centre of the vent. C Plan view spectral decomposition of the cinder cone in B highlighting how different it is from the surrounding sediments. D Oblique view of the same cinder cone shown in TWT. E Cross section through a Maar-diatreme, adapted from Nemeth \& Kereszturi 1290 (2015). F Seismic line across a proposed Maar-diatreme from the Winnie 3D survey. Note how it cuts 1291 down into the subsurface with an internally chaotic seismic response. G Plan view spectral decomposition of a Maar-diatreme. H Oblique, TWT view of the proposed Maar-diatreme. 


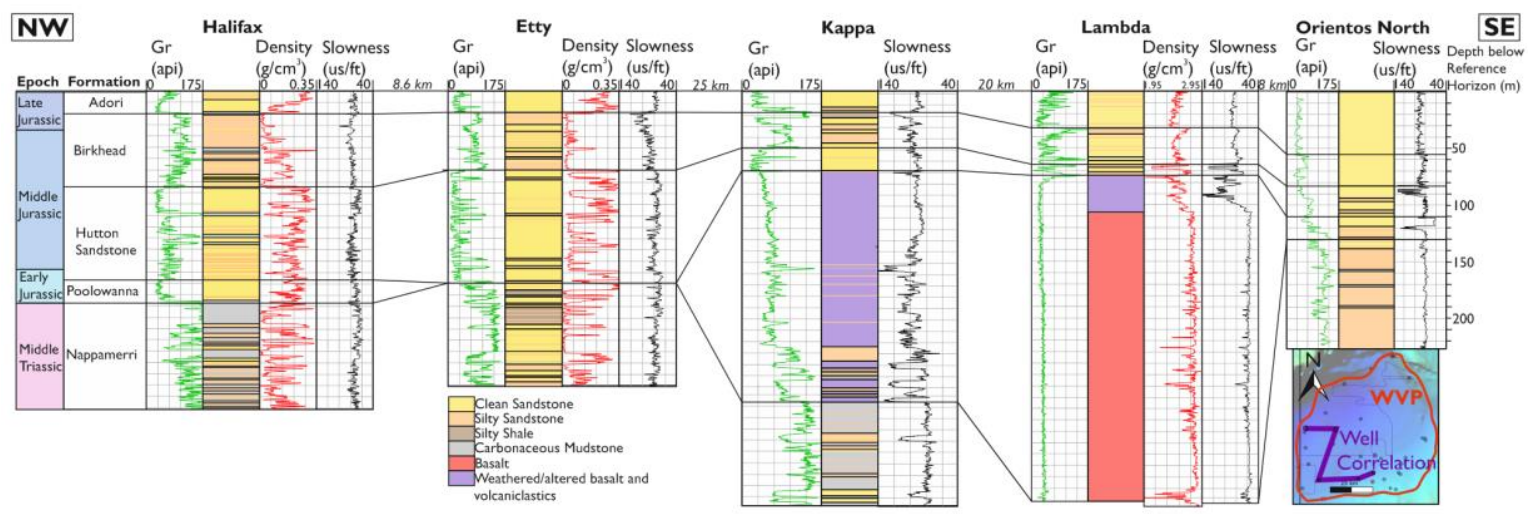

Figure 5. Well correlation across the eastern Nappamerri Trough showing the changes in facies 1298 across the area and the thickness of the volcanics intersected. Note in areas of thickened volcanics 1299 (i.e. the Kappa and Lambda wells) the Hutton sandstone and Birkhead fm. are thinned considerably 1300 suggesting sedimentary systems were diverted away from areas of eruption. As noted in the text, the 1301 change from the clean sandstones of the Hutton Sandstone to silty sandstones in the Birkhead fm. is associated with an influx of volcanic arc derived sediment from eastern Australia. 


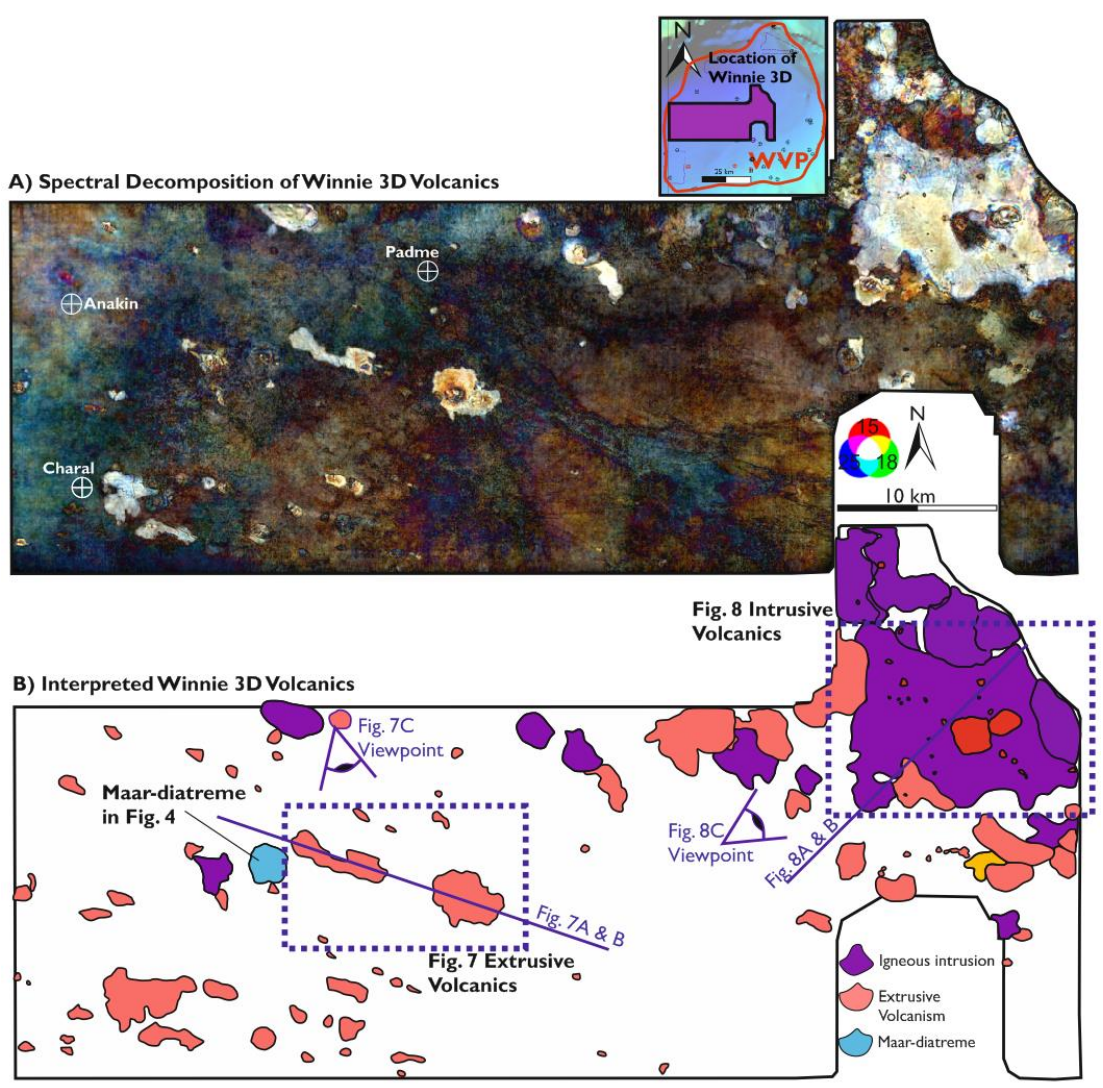

1306 Figure 6. Spectral decomposition of a horizon mapped across the volcanics of the Winnie 3D survey. A Uninterpreted spectral decomposition. B Interpreted spectral decomposition highlight extrusive volcanics and the location of igneous intrusions. Note the increased number of intrusions towards the north east of the Winnie 3D survey. 

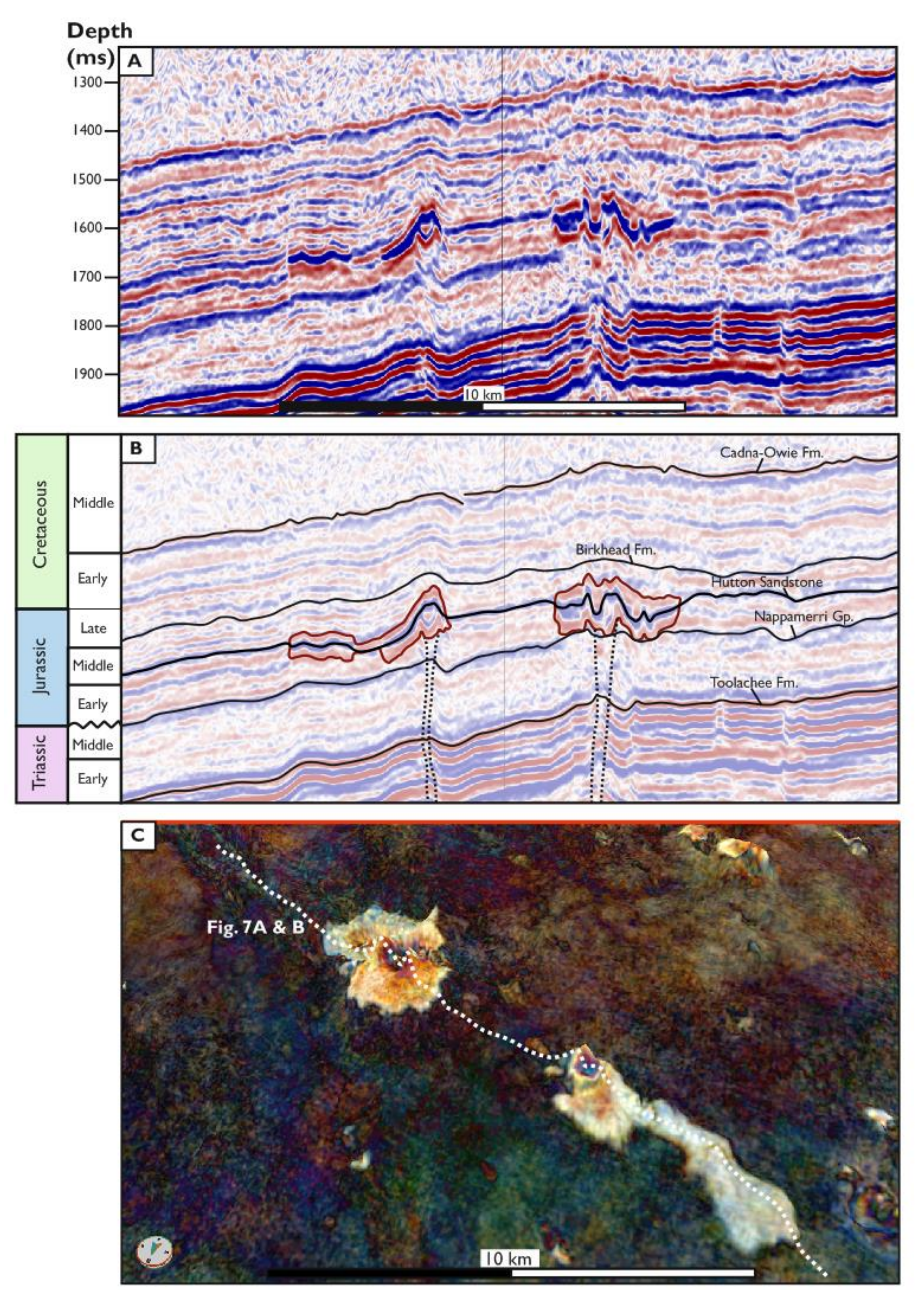

1311 Figure 7. 3D Seismic across two monogenetic vents that extend into surface flows, from the Winnie 1312 3D survey. A Uninterpreted line across the vents. B Interpreted line across the vents. Not the vertical 1313 zone of disrupted seismic directly below the vents, indicative of underlying plumbing system that fed 1314 the flows. C Spectral decomposition of a horizon mapped across the vents, highlighting their 3D morphology. 


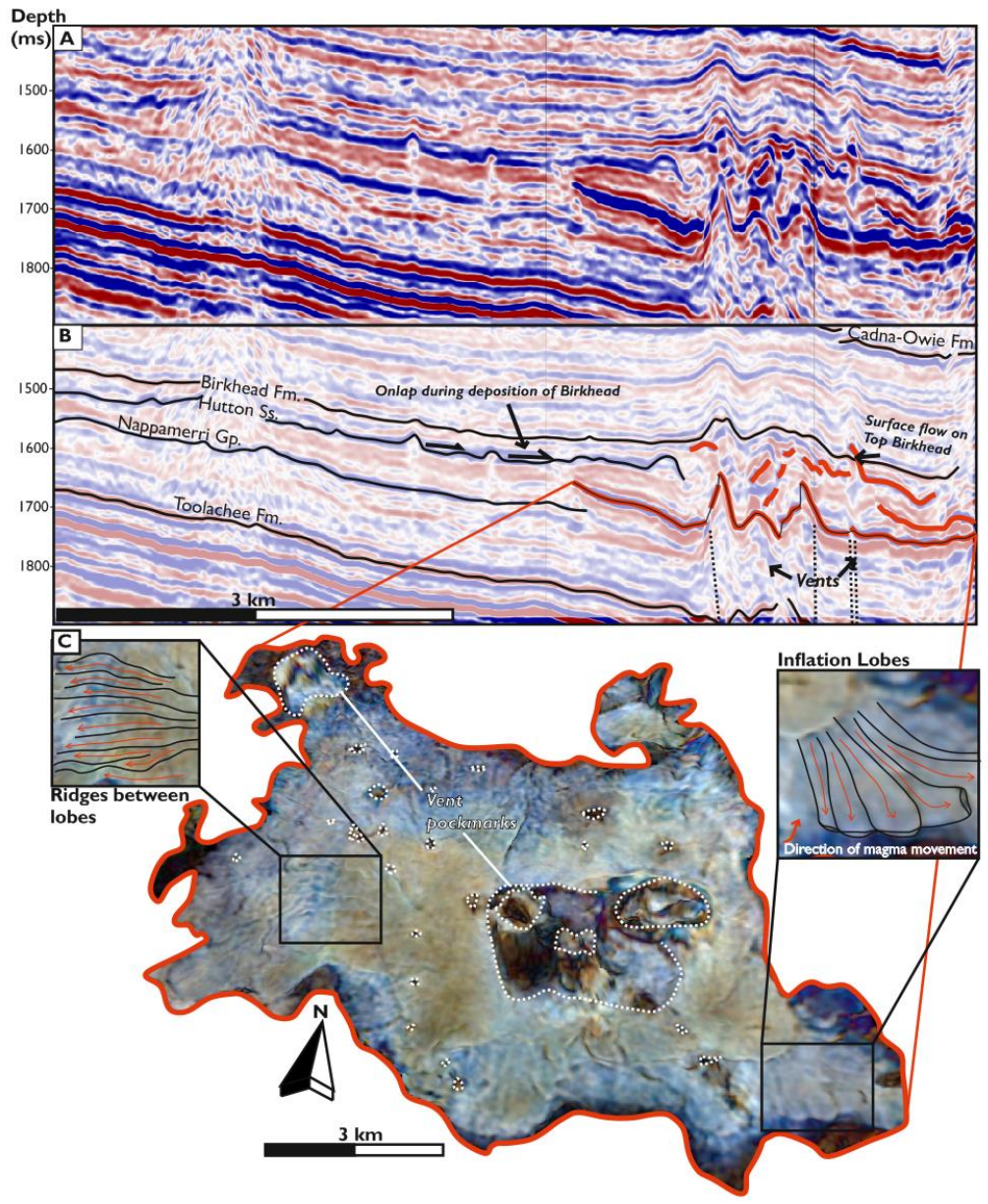

1317 Figure 8. Seismic across the large intrusion in the Winnie 3D survey. A Uninterpreted seismic line.

1318 B Interpreted seismic line, illustrating the uplift of the overburden and the numerous vents and 1319 overlying volcanics associated with the intrusion. C Spectral decomposition of the intrusion, highlight 1320 the pockmarks of vents that pass through the intrusion and morphological characteristics associated 1321 with the intrusion. 


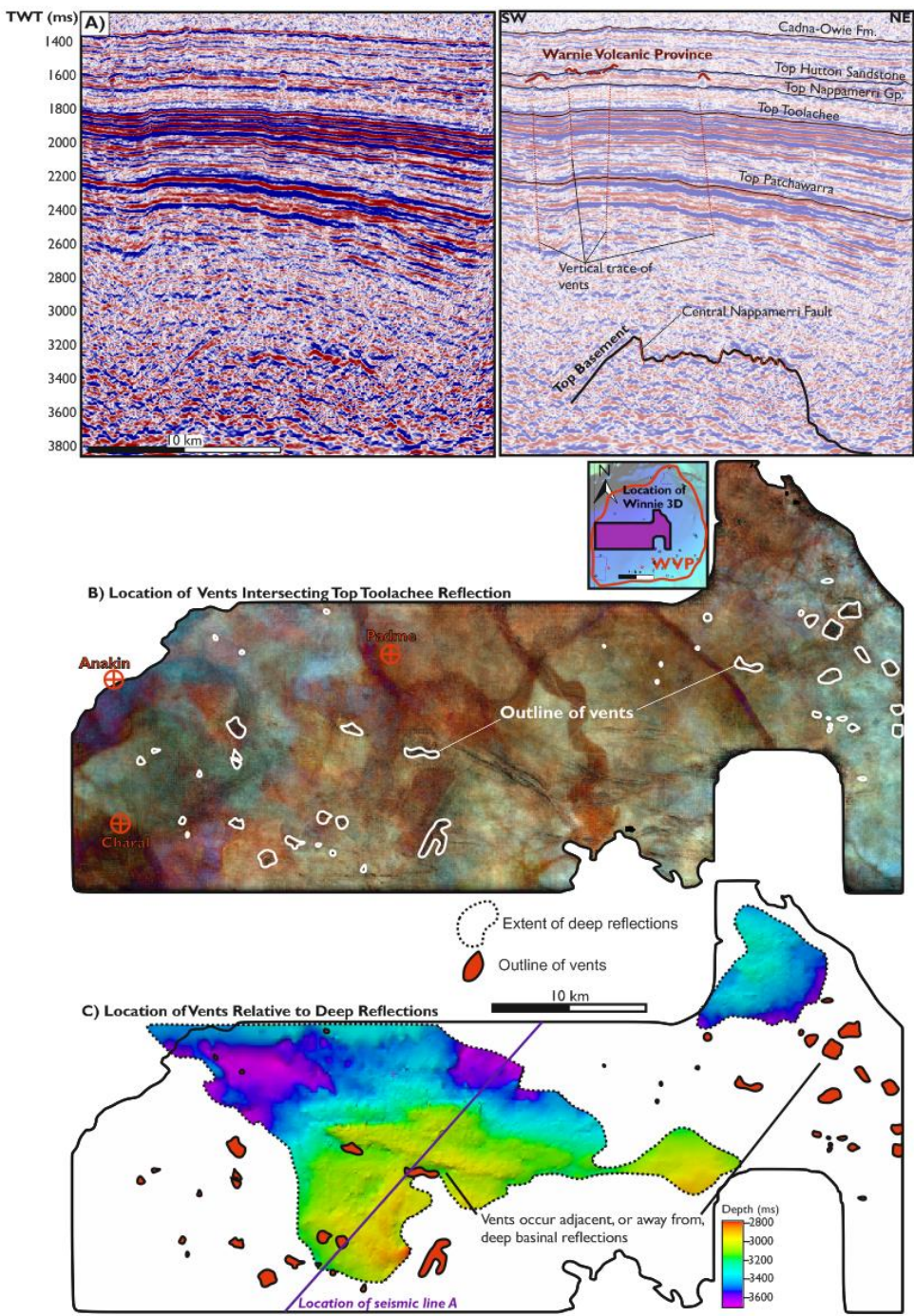

1323 Figure 9. The basement structure and it's relation to vents within the Winnie 3D survey. A 1324 Uninterpreted and interpreted seismic line across the Winnie 3D survey, highlighting the deep 1325 basement reflections and their relation to vents feeding the WVP. B Spectral decomposition of the 1326 Top Toolachee horizon, highlighting the location of vents underlying the WVP. C Location of vents mapped using the Top Toolachee horizon superimposed on a TWT map of the top basement horizon. 


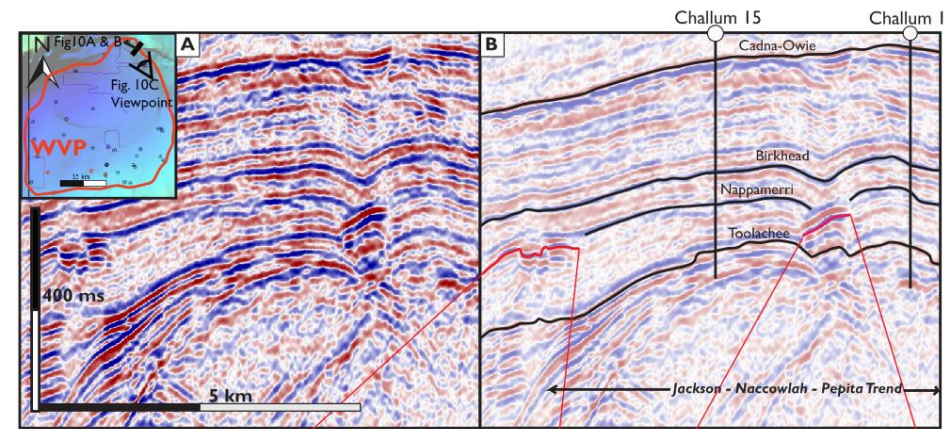

C RMS Amplitude

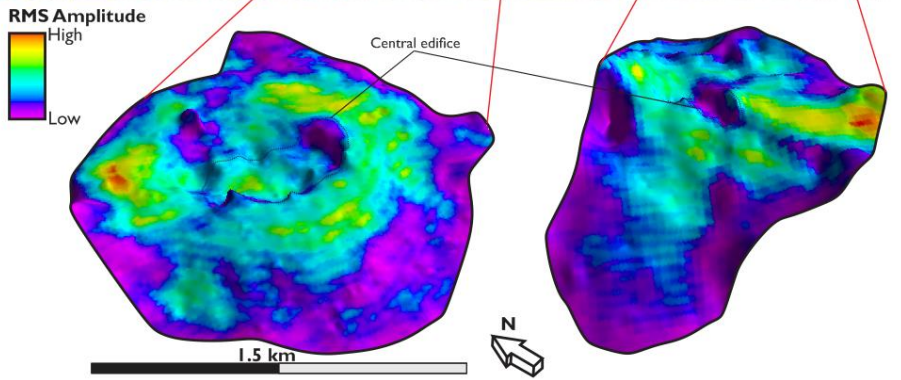

1329 Figure 10. Seismic across volcanics within the Madigan 3D survey. A Uninterpreted seismic line taken across the two volcanic features. B Interpreted seismic horizon, showing the location of two Challum wells and the Challum vents. C 3D view of the Challum vents, with an RMS amplitude extraction draped over the horizons. 


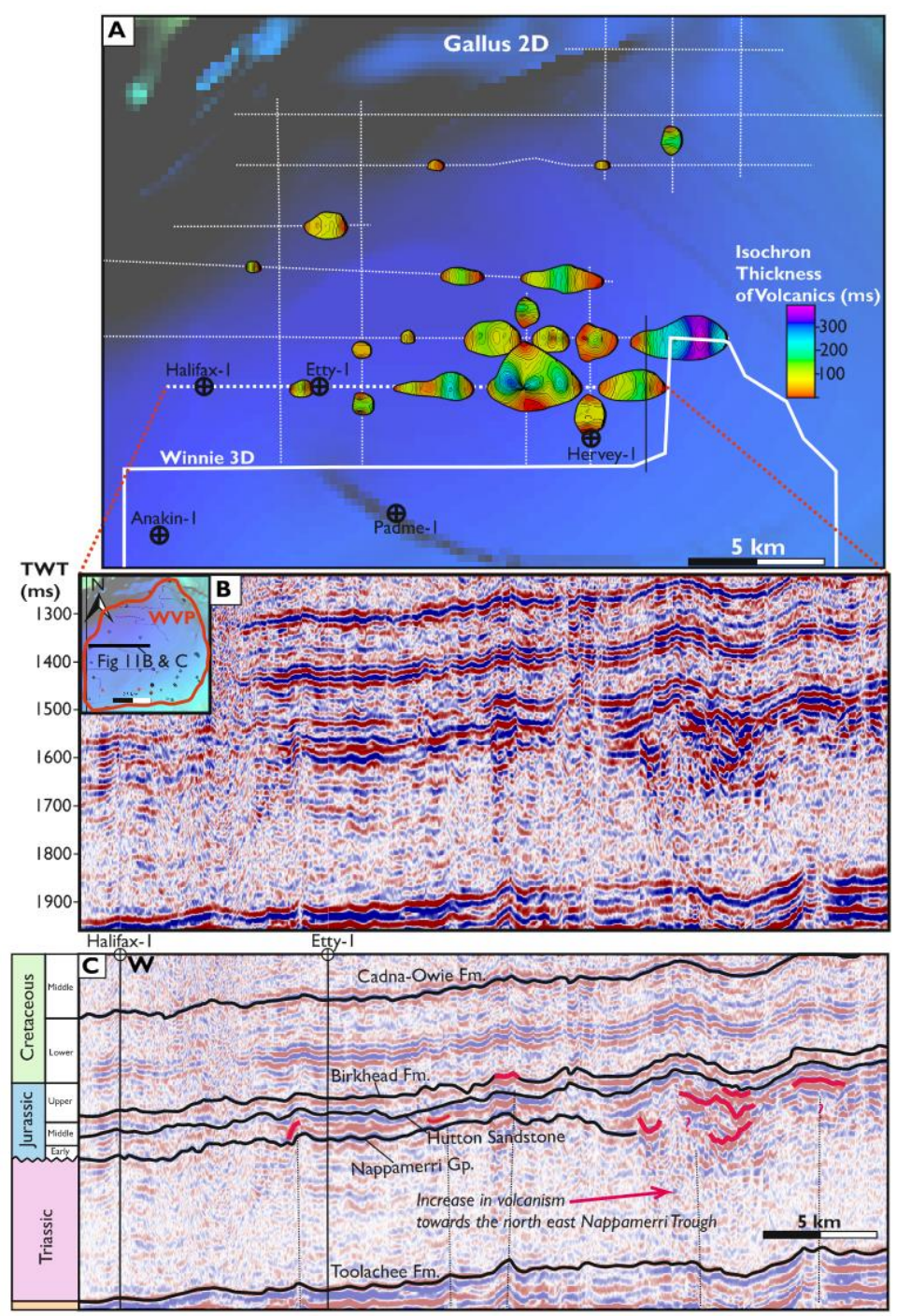

1334 Figure II. Seismic images of the Gallus 2D survey. A Isochron thickness map of the volcanics 1335 identified throughout the Gallus 2D survey. B Uninterpreted seismic line from the Gallus 2D survey. 1336 C Interpreted seismic line from the Gallus 2D survey. An increase in the volume of volcanics towards the east of the survey is apparent. 

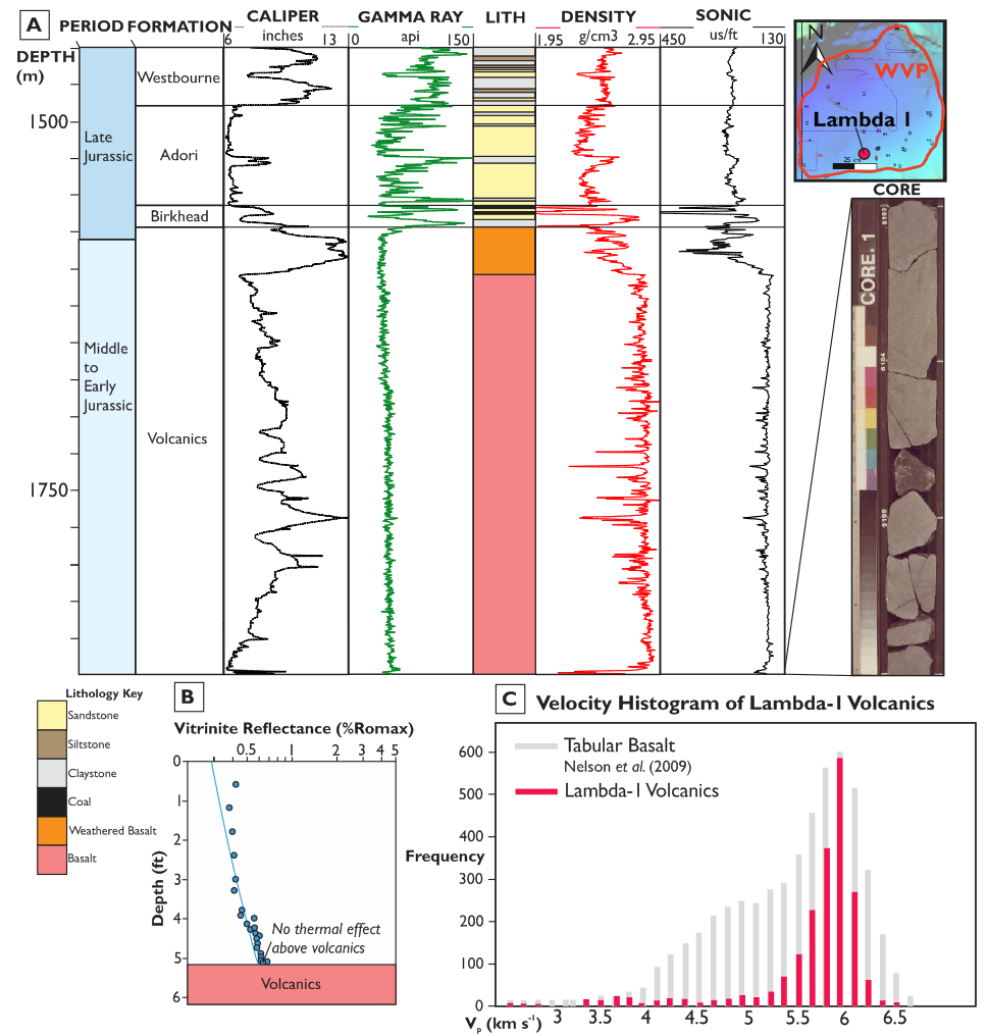

1339 Figure 12. Well data for the volcanics from the Lambda-I well. A Composite log of the volcanic succession in the Lambda-I well. Includes an image of the core taken from the base of the volcanic successon. B Vitrinite reflectance curve for the succession above the volcanics taken from Boothby (1986). Little thermal effect is observed. C Velocity histogram of the Lambda-I volcanics superimposed on Nelson et al.'s (2009) velocity histogram of Tabular basalt. 


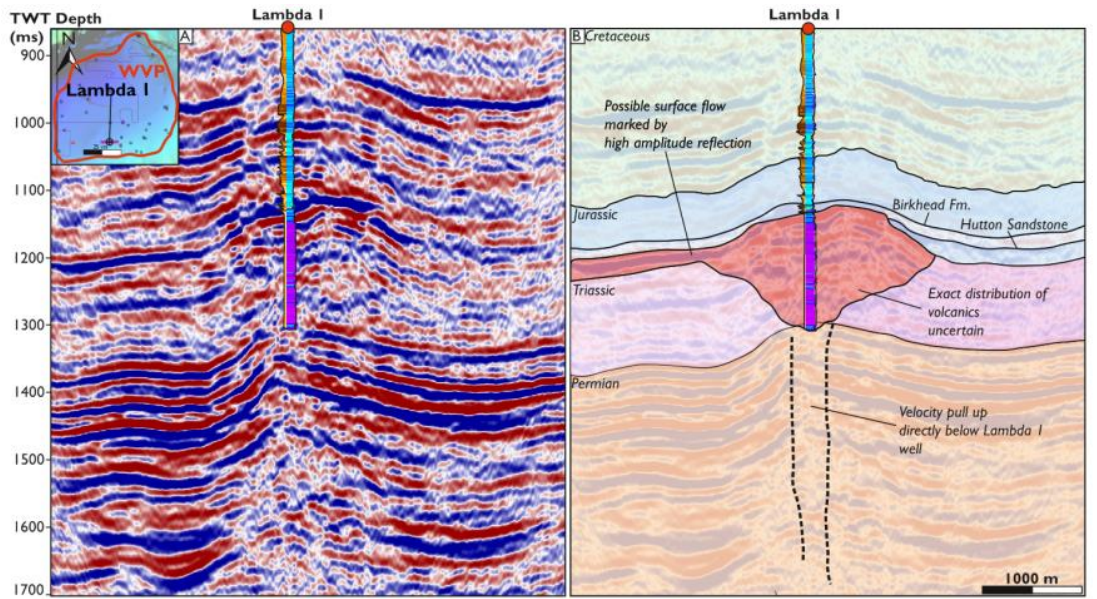

1346 Figure 13. West to east seismic line running across the Lambda I well. The extent of the Lambda I 1347 vent has been inferred base on the thickness of volcanics within the well. 


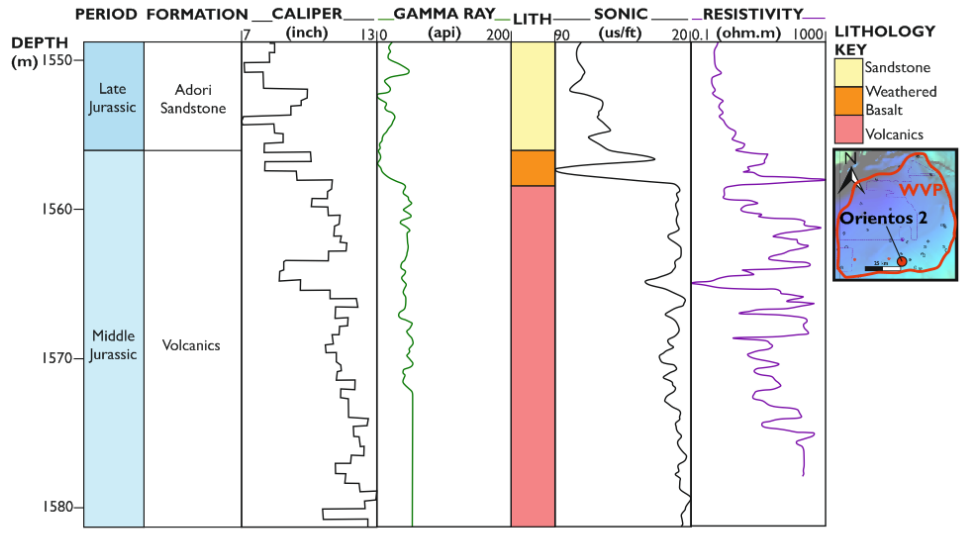

1351

1352 Figure I4. Digitised composite log for the volcanics within the Orientos 2 well. 

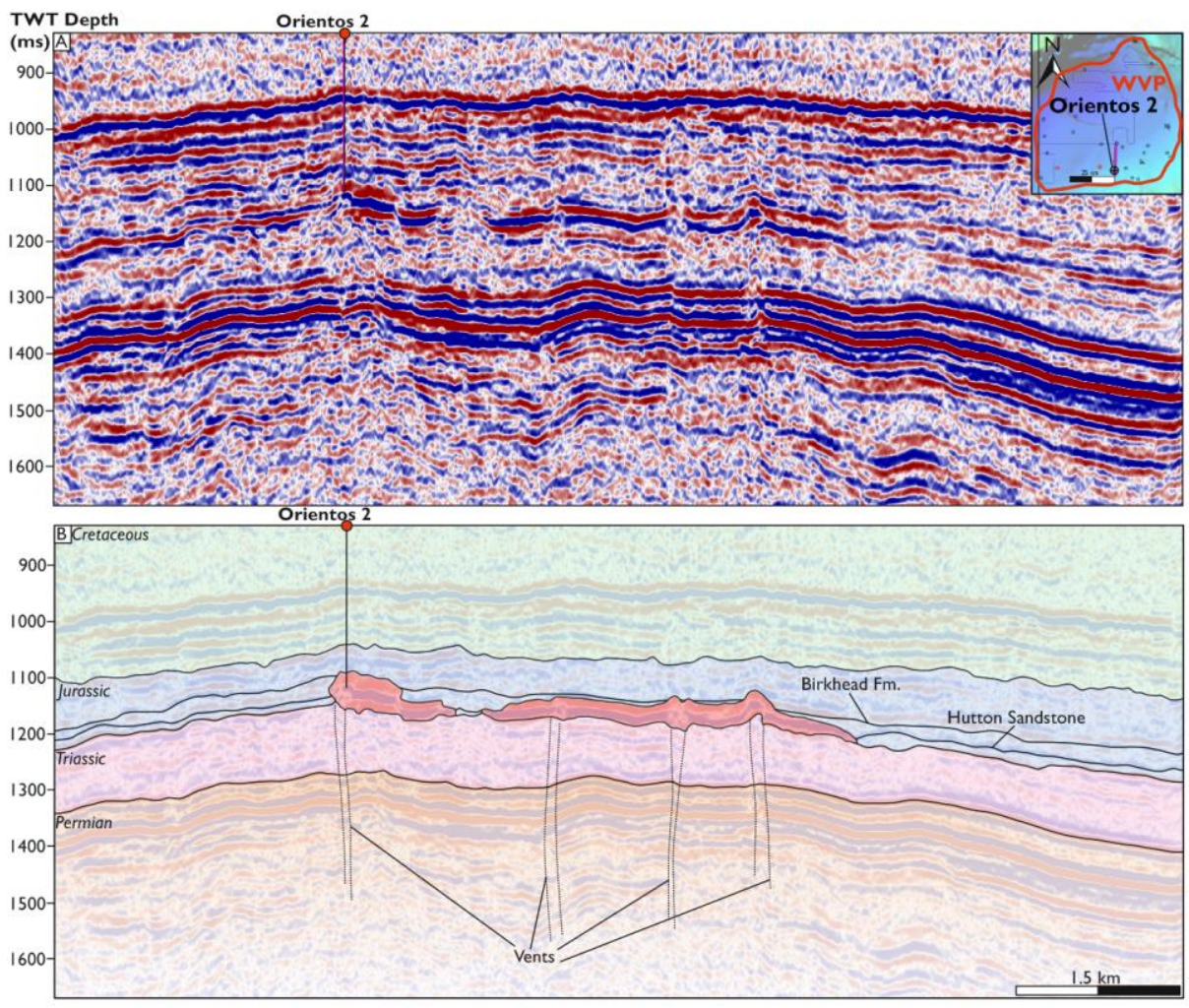

1355 Figure 15. South to North 2D seismic line running across the location of the Orientos 2 well. A series of tabular basalt lava flows emplaced on top of the Triassic Nappamerri group are visible, with

1357 Orientos 2 intersecting the top of the southernmost flow. 


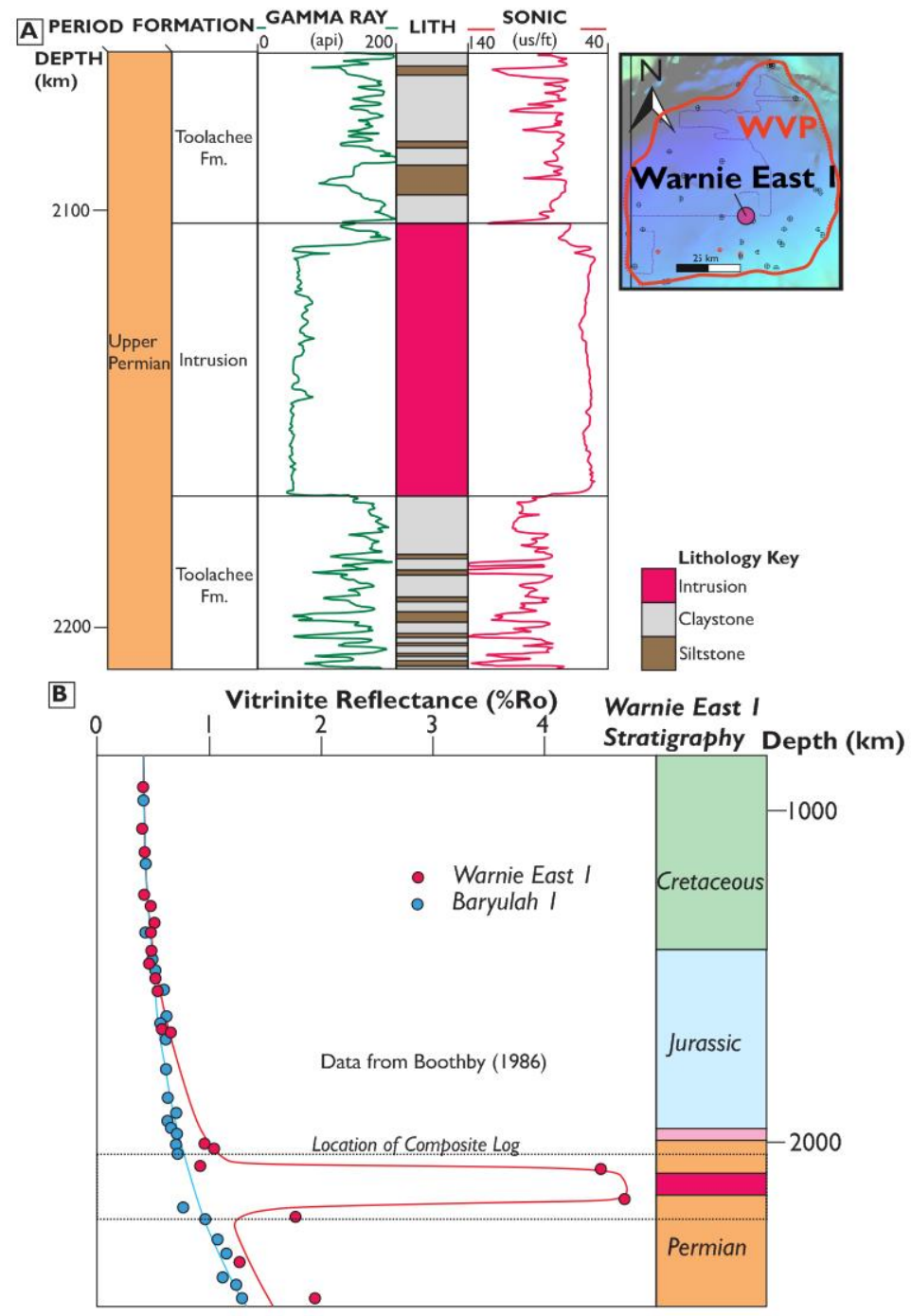

1361

1362 Figure 16. Well data for intrusive volcanic rocks within the Warnie East I well. A Composite log 1363 across the intrusion in the Warnie East well. B Vitrinite reflectance profile across the intrusion in the 1364 Warnie East well taken from Boothby (1986). Thermal effect both above and below the well is noted. 


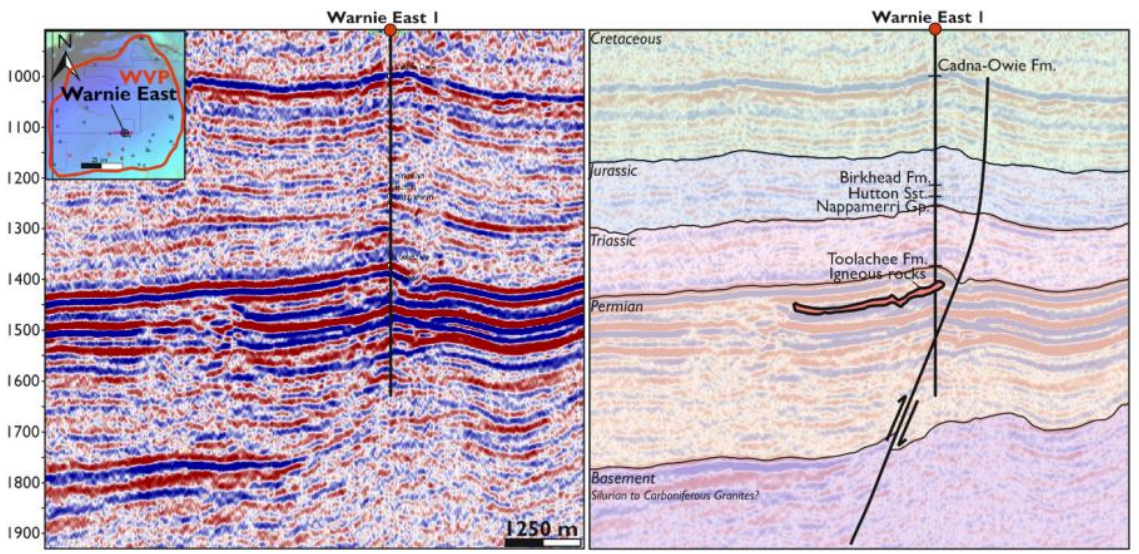

1367 Figure 17. 2D seismic line running from west to east across the Warnie East I well. The exact 1368 location of the igneous rocks is unclear on the line, however, a shallow saucer-shaped reflection with 1369 the Toolachee Fm. intersects Warnie East I at the depth igneous rocks are found. Also notable is the presence of a rollover anticline adjacent to a growth fault.

1371 


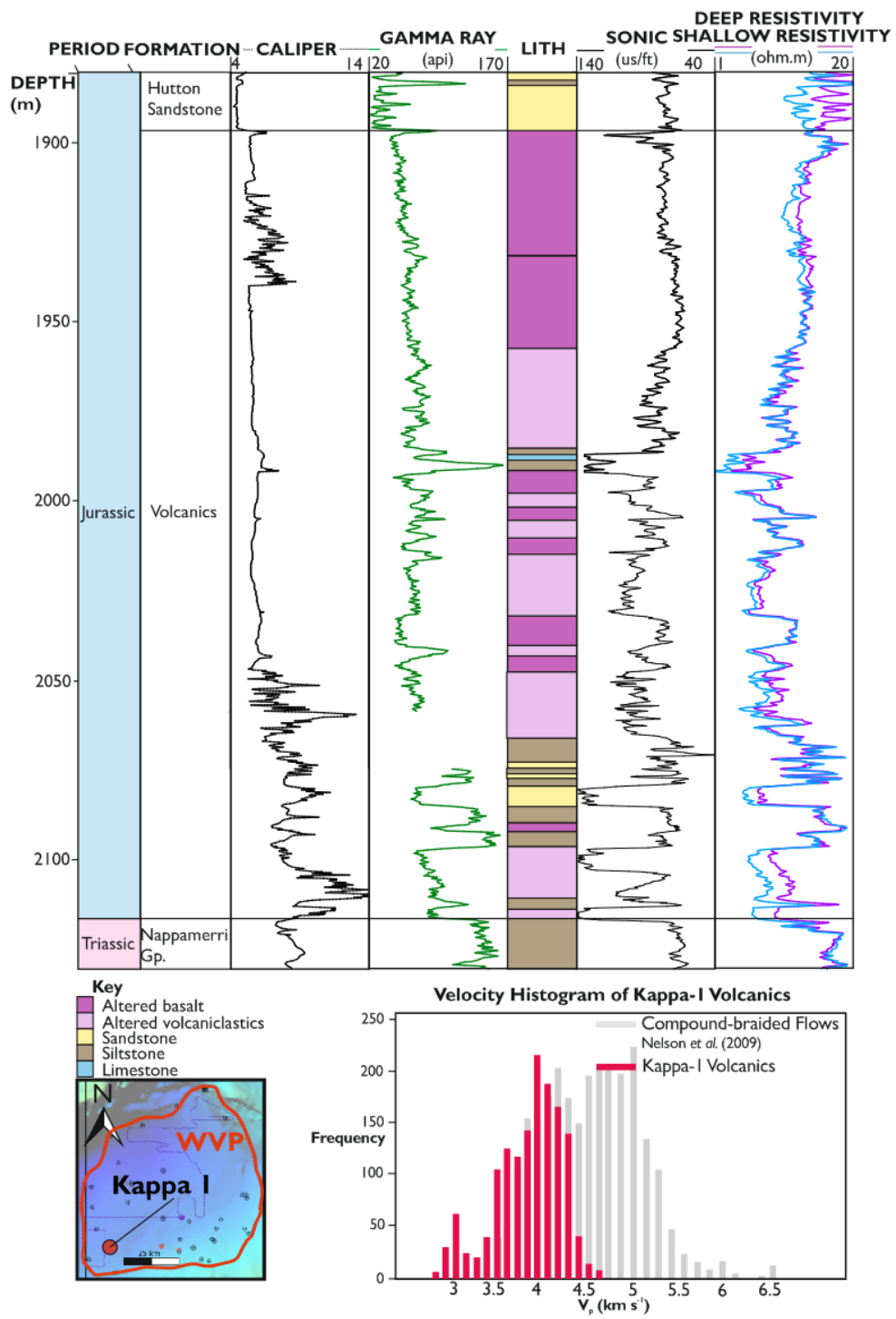

1375 Figure 18. Well data for the Kappa-I well. A Composite log for the Kappa-I well volcanics. B 1376 Velocity histogram for the Kappa-I well volcanics, superimposed on top of Nelson et al.'s (2009) 1377 velocity histogram for compound-braided volcanics. 


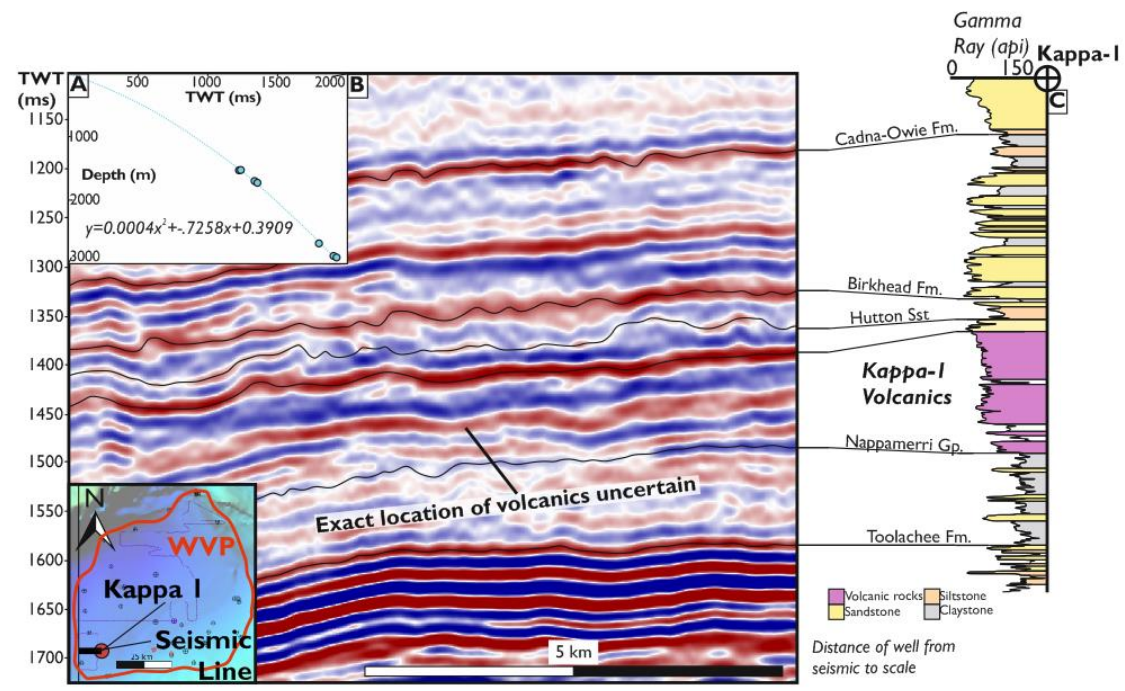

1379 Figure 19. Position of the Kappa-I well in relation to the Snowball 3D survey. A TWT to depth relationship used to convert the Kappa-I well data from depth to time in order to display it adjacent to the Snowball 3D survey. B Line across the Snowball 3D survey with the position of formation tops based on the Kappa-I well displayed. C Gamma ray curve from the Kappa-I well with formation tops marked. 

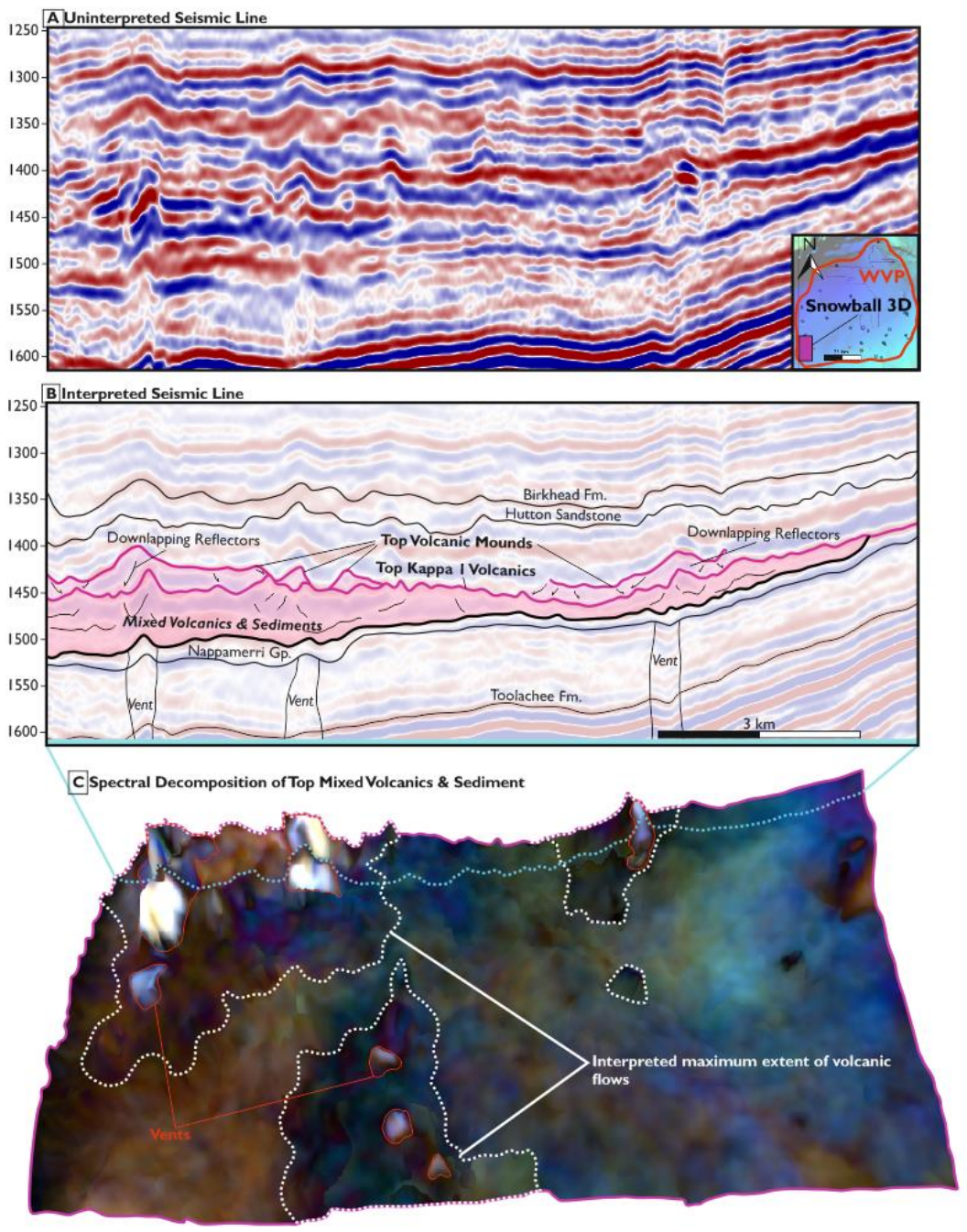

1385 Figure 20. Seismic across volcanics within the Snowball 3D survey. A Uninterpreted seismic line. B Interpreted seismic line. Thick package of mixed volcanics \& sediments based off of the Kappa-I well volcanics. C Spectral decomposition of the top mixed volcanics \& sediment horizon. Location of vents noted by bright white colour with interpreted flow fields based on dark colours adjacent to vents. 

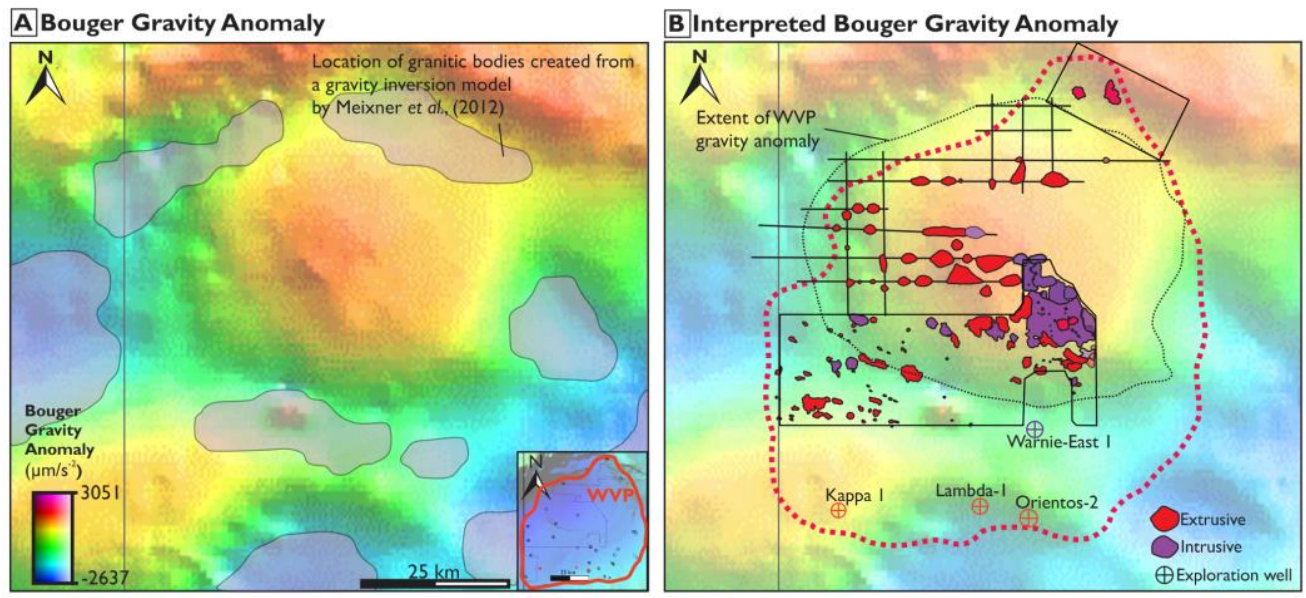

1392 Figure $2 \mathbf{2}$. Bouger gravity anomaly adopted from Tracey \& Bacchin (2008). The gravity data shows 1393 spherical cap-corrected Bouger anomalies with a high pass filter with a cut-off wavelength of $500 \mathrm{~m}$. 1394 Spacing coverage is typically II km, with more closely spaced grids $(2 \mathrm{~km})$ in areas of economic interest 1395 (Tracey \& Bacchin, 2008). A. Uninterpreted bouger gravity anomaly overlain with the location of granitic bodies created from Meixner et al.'s (2002). Granitic bodies are expressed as lower values in the gravity anomaly, located adjacent to the $50 \times 50 \mathrm{~km}$ gravity high below the Warnie Volcanic Province. B. Bouger gravity anomaly superimposed with the location of the igneous rocks within the Warnie Volcanic Province. 


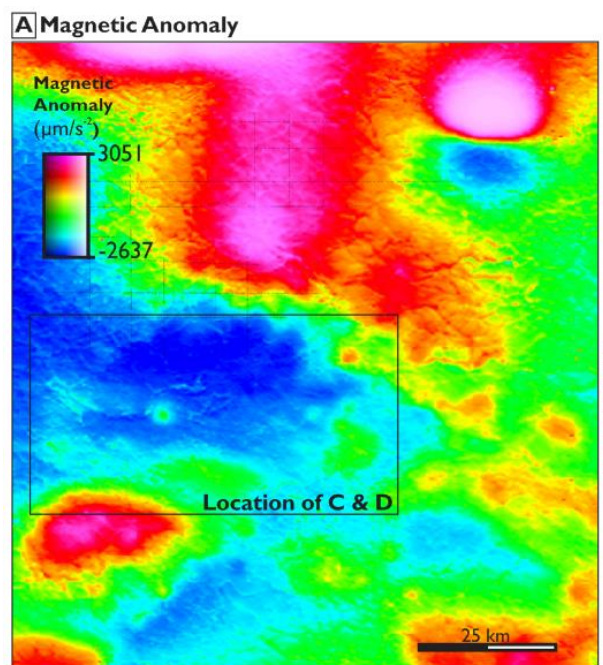

C Magnetic Anomaly focused on the Winnie 3D survey

N

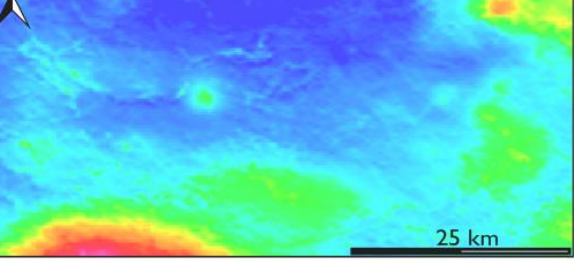

B Interpreted Magnetic Anomaly

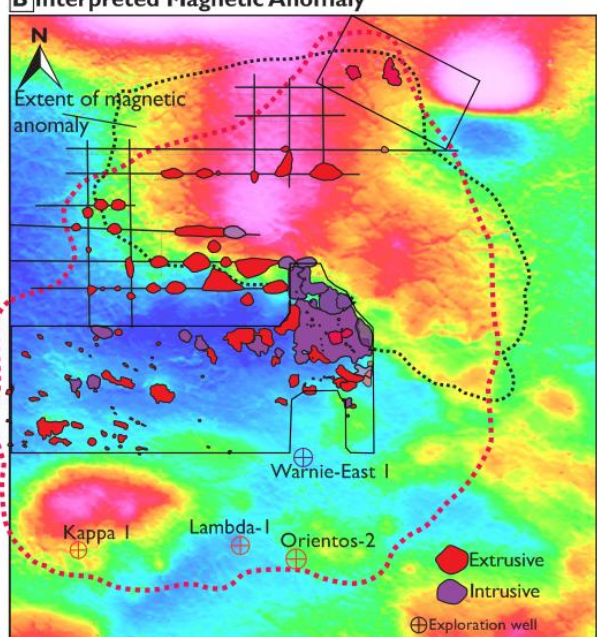

Interpreted Winnie 3D survey Magnetic Anomaly

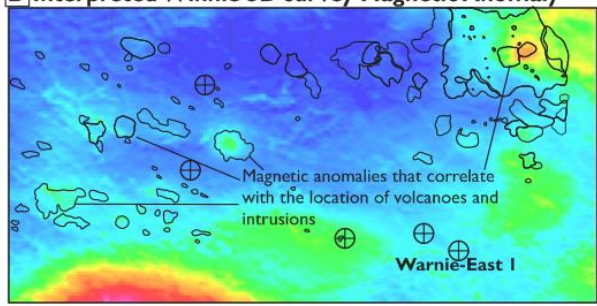

1402 Figure 22. Total magnetic intensity across the Warnie Volcanic Province. This data was obtained for 1403 study from the Queensland Department of Natural Resources and Mines database. The survey was 1404 flown in an east-west direction at a height of $60 \mathrm{~m}$ with a distance of $400 \mathrm{~m}$ between the traverse lines. A. Unannotated total magnetic intensity over the eastern Nappamerri Trough. Location of C and $\mathrm{D}$ highlighted. B. Total magnetic intensity superimposed with the location of igneous rocks interpreted within the Warnie Volcanic Province. C Unannotated total magnetic intensity for the area covered by the Winnie 3D survey. D Total magnetic intensity superimposed with the location of igneous rocks interpreted within the Winnie 3D survey. Note the close correspondence between some magnetic anomalies and the location of igneous rocks. 

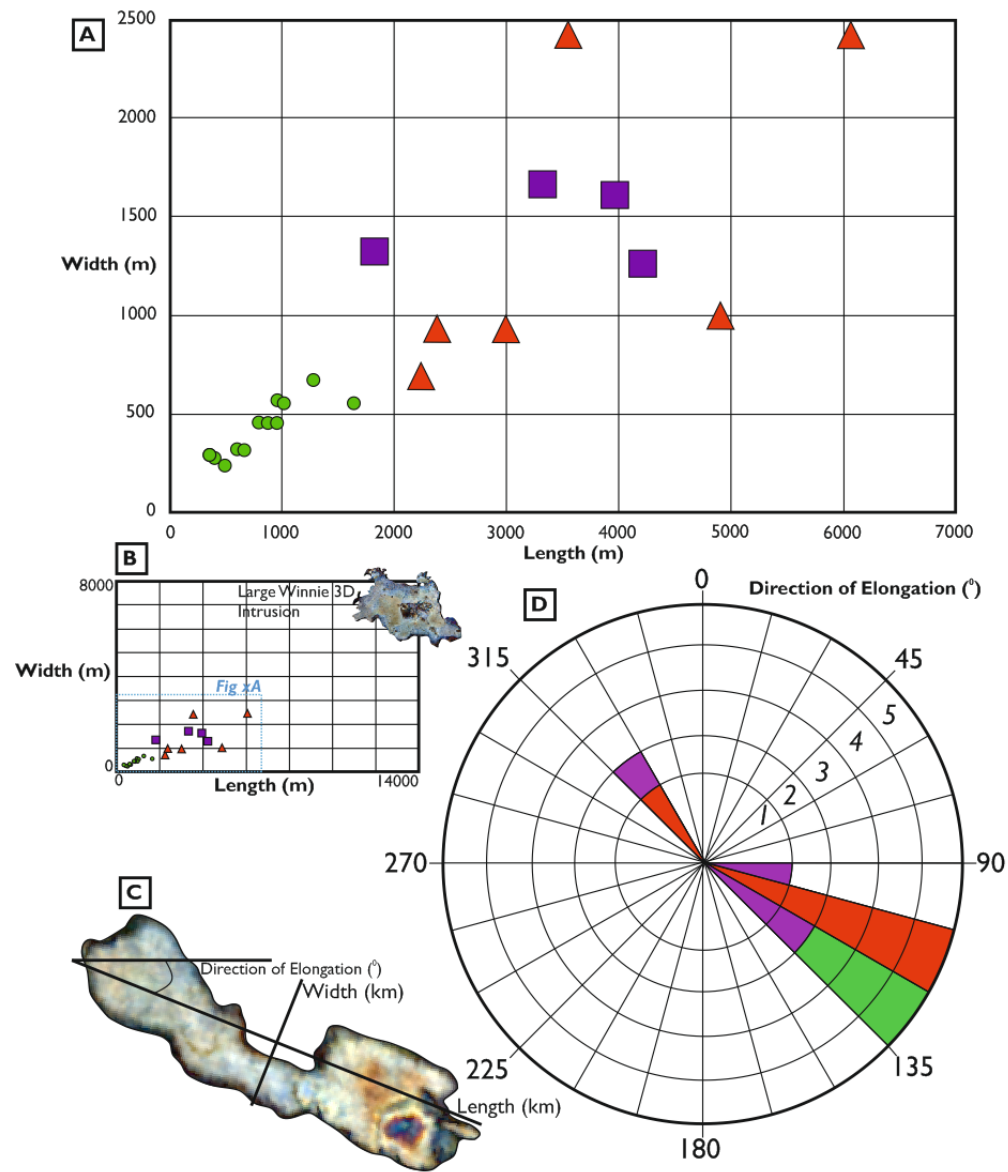

1413

1414 Figure 23: Size and orientation of volcanics within the Winnie 3D and Madigan 3D surveys. A Size of vents, intrusions and volcanic flows. B Figure A, with the singular large intrusion superimposed on

1416 it, highlighting the shear the scale of this volcanic features. C Measurements taken for each individual 1417 volcanic feature. D Direction of elongation for the volcanics, highlighting that they are elongate in a 1418 SE-NW direction. 


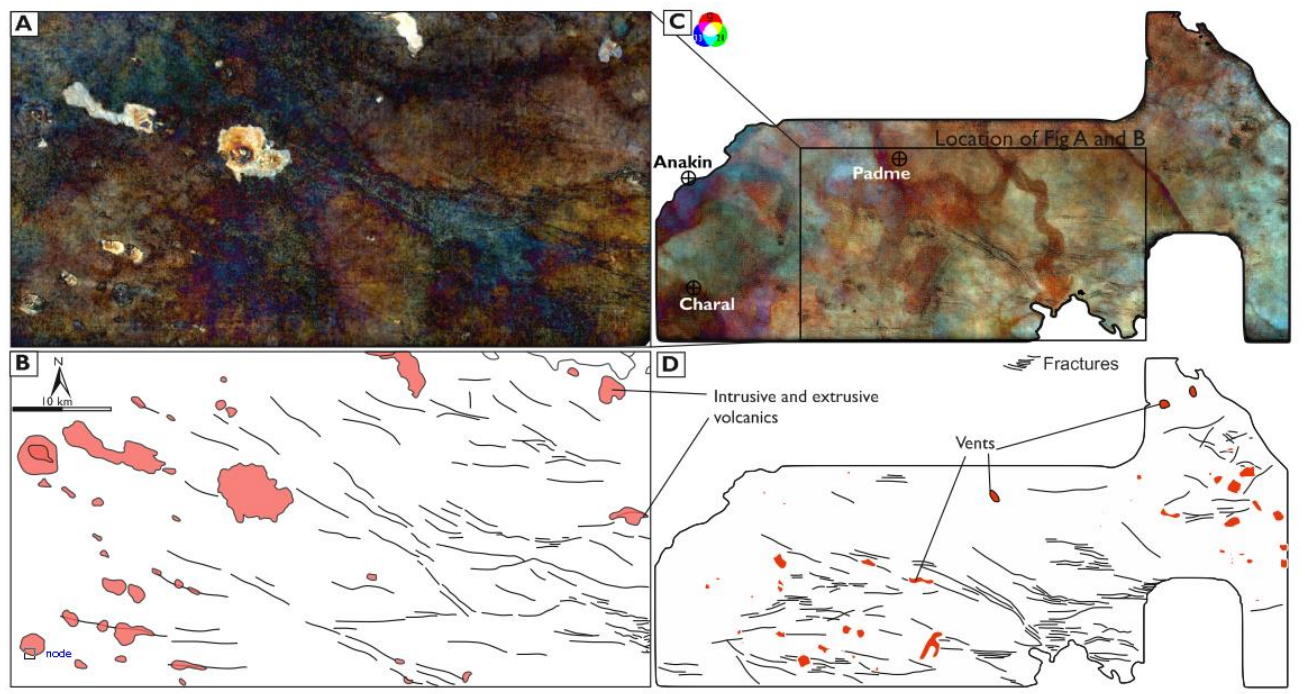

1421 Figure 24: Mapping of minor faults within the Nappamerri trough. A Spectral decomposition of the 1422 Top Volcanics horizon from the Winnie 3D survey. B Interpretation of A with discontinuities and 1423 the location of volcanics highlighted. C Spectral decomposition of the Top Toolachee horizon. D 1424 Interpretation of discontinuities within the Toolachee Horizon and the location of volcanics 1425 highlighted. 


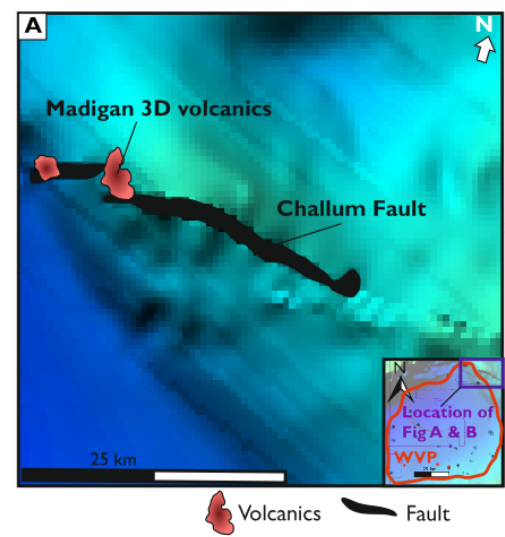

1428 Figure 25: A Location of the Challum Fault and Madigan 3D volcanics superimposed on a Depth to 1429 top basement map adapted from NGMA (2003). Madigan 3D volcanics located above the North 1430 West tip of the Challum Fault. 


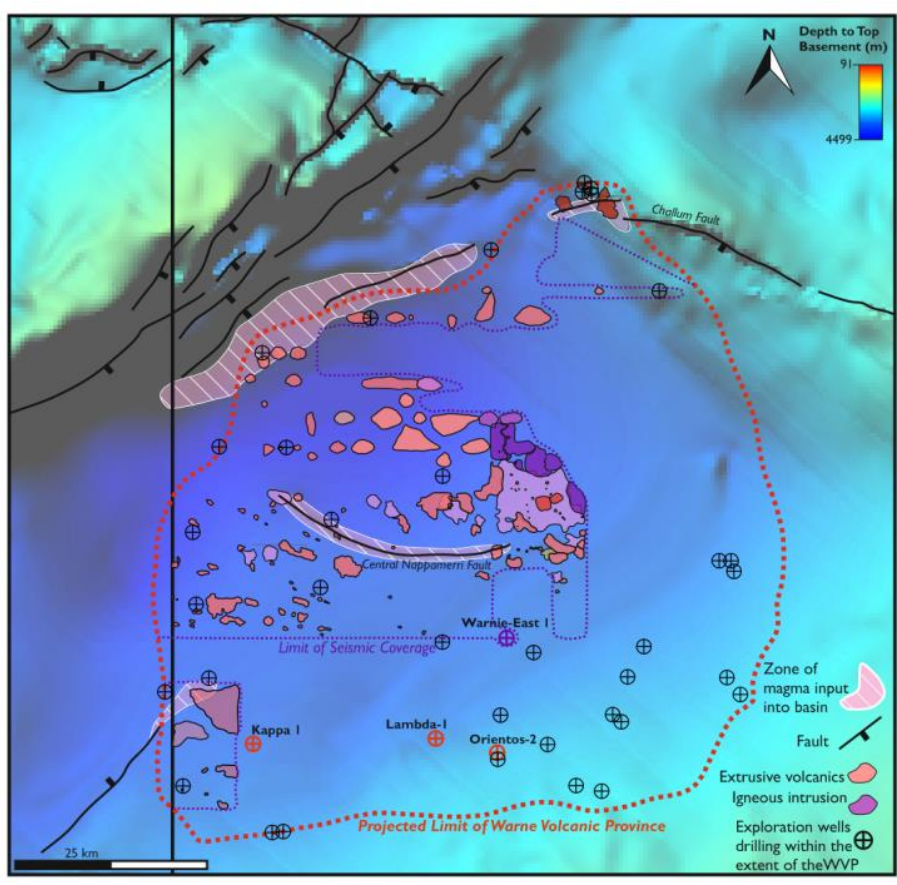

1435 Figure 26: Regional map of the Warnie Volcanic Province. Depth to top basement map adapted from NGMA (2003). Location of extrusive volcanics and igneous intrusions based on seismic data.

1437 The volcanics, however, are thought to extend beyond the limit of seismic coverage towards the 1438 projected limit of the Warnie Volcanic Province. Zones of magma input into the basin are based off 1439 of the main basement bounding faults identified within the study, although many more minor input 1440 points are expected to occur within the Nappamerri trough from faults not imaged within this study. 


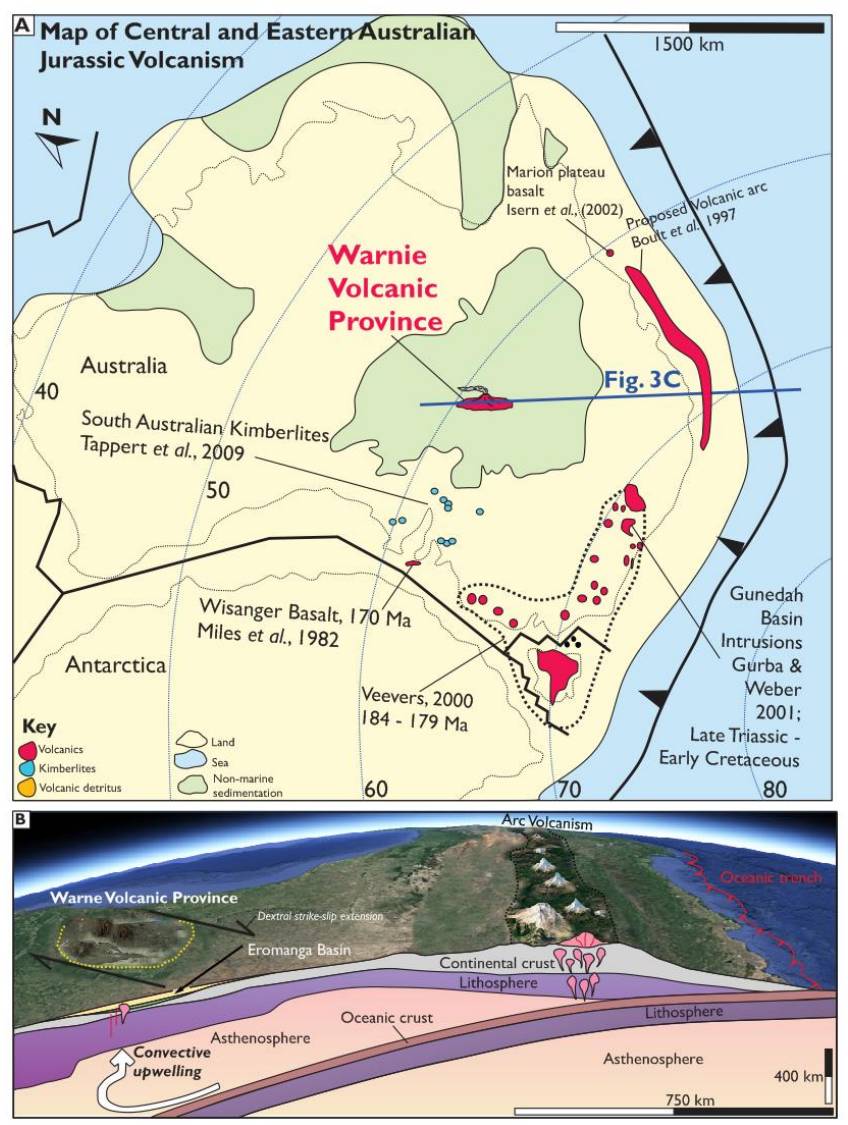

1443 Figure 27: A Map of Australia, superimposed with the location of middle to late Jurassic volcanics 1444 in eastern Australia, described in the text. Base map is a magnetics map used to highlight the Great 1445 Artesian Basin. B Palaeogeographic map of Australia in the middle Jurassic (Oxfordian, I60 Ma), highlighting the tectonic nature of the different volcanics. C Oblique view of Australia, highlighting the subducting pacific slab and associated convective upwelling. Steps in lithospheric thickness have adapted from Fishwick et al., (2008). 